BNL- 66160

INFORMAL REPORT

\title{
DEVELOPMENT OF A LOW PRESSURE, AIR ATOMIZED OIL BURNER WITH HIGH ATOMIZER AIR FLOW
}

\section{PROGRESS REPORT FY 1997}

Thomas A. Butcher

January 1998

Prepared for:

Office of Building Equipment

Office of Building Technology, State and Community Programs United States Department of Energy

Washington, DC 20585

Energy Efficiency and

Conservation Division

DEPARTMENT OF APPLIED SCIENCE

BROOKHAVEN NATIONAL LABORATORY

UPTON, LONG ISLAND, NEW YORK 11973

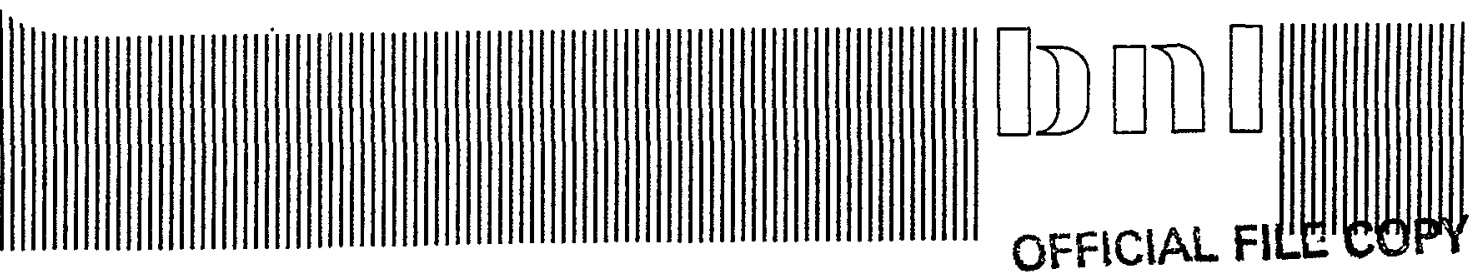





\title{
DEVELOPMENT OF A LOW PRESSURE, AIR ATOMIZED OIL BURNER WITH HIGH ATOMIZER AIR FLOW
}

\author{
PROGRESS REPORT FY 1997
}

BY:

THOMAS A. BUTCHER

\section{JANUARY 1998}

\section{Prepared for:}

Office of Building Equipment

Office of Building Technology, State and Community Programs United States Department of Energy Washington, DC 20585

Under Contract No. DE-AC02-98CH10886

Brookhaven National Laboratory Upton, NY 11973-5000 


\section{ACKNOWLEDGEMENTS}

Two individuals contributed greatly to this project. Yusuf Celebi, Chemical Engineer on the BNL staff deserves credit for the development work in the laboratory. Mr. Len Fisher, BNL consultant, contributed many important suggestions.

The author would also like to acknowledge important efforts and input from BNL engineers:

George Wei, Richard Krajewski, and Roger McDonald. 


\section{TABLE OF CONTENTS}

\section{Page}

ACKNOWLEDGEMENTS $\ldots \ldots \ldots \ldots \ldots \ldots \ldots \ldots \ldots \ldots \ldots \ldots \ldots \ldots$ iii

ABSTRACT $\ldots \ldots \ldots \ldots \ldots \ldots \ldots \ldots \ldots \ldots \ldots \ldots \ldots \ldots \ldots \ldots \ldots \ldots \ldots \ldots \ldots$

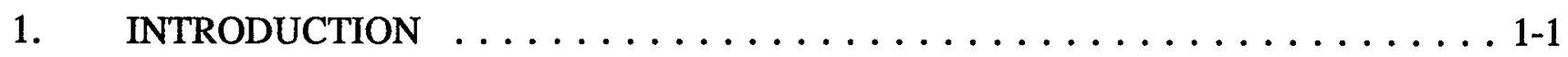

2. CHARACTERISTICS OF THE ATOMIZING NOZZLE $\ldots \ldots \ldots \ldots \ldots \ldots$

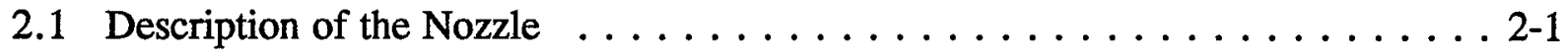

2.2 Experimental Methods Used in Nozzle Characterization . . . . . . . . 2-1

2.3 Results of Characterization Tests . . . . . . . . . . . . 2-1

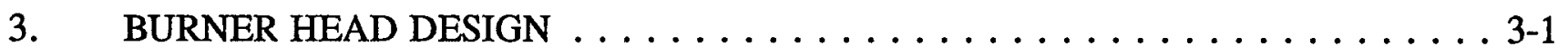

4. COMBUSTION PERFORMANCE $\ldots \ldots \ldots \ldots \ldots \ldots \ldots \ldots \ldots \ldots$ 4-1

4.1 Characterization Test in Quartz Combustion Chamber $\ldots \ldots \ldots \ldots \ldots$. . . . .

4.2 Tests of Ignition Point Location . . . . . . . . . . . . . . .

4.3 Combustion Tests in Selected Heating Appliances ........... . . .

5. CONCLUSIONS AND FUTURE PLANS $\ldots \ldots \ldots \ldots \ldots \ldots \ldots \ldots \ldots \ldots$

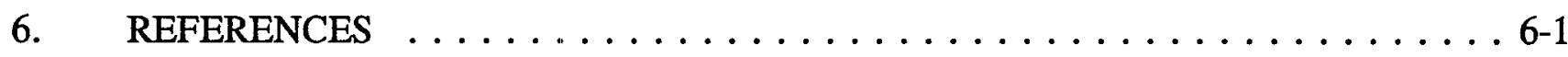

LIST OF FIGURES $\ldots \ldots \ldots \ldots \ldots \ldots \ldots \ldots \ldots \ldots \ldots \ldots \ldots$

LIST OF TABLES $\ldots \ldots \ldots \ldots \ldots \ldots \ldots \ldots \ldots \ldots \ldots \ldots \ldots \ldots \ldots \ldots \ldots$ vii 


\section{List of Figures}

Figure 1-1 Illustration of air distribution around the head of a conventional, pressure-

Page

atomized retention head burner ..................... 1-2

Figure 2-1 General illustration of the low-pressure, air atomizing nozzle showing air

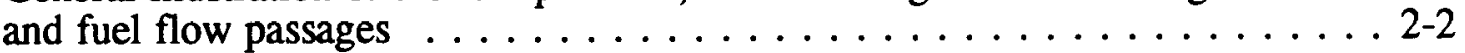

Figure $2-2 \quad$ Photo illustration of nozzle components $\ldots \ldots \ldots \ldots \ldots$. . . . . . . . . .

Figure $2-3 \quad$ Basic flow/pressure relationship for atomizing nozzle $\ldots \ldots \ldots \ldots$

Figure 2-4 Radial profiles of axial velocity at three axial distance from nozzle face. Air

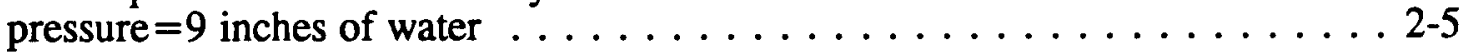

Figure 2-5 Results of atomization tests with nozzle at 6 and 8 inches of air pressure . . . 2-6

Figure 2-6 Results of spray pattern test with nozzle. Air pressure $=8$ inches

of water. Oil flow $=0.5$ Gallons Per Hour $\ldots \ldots \ldots \ldots$. . . . . . . . .

Figure 3-1 CFD prediction of the radial distribution of the axial velocity and the angular velocity at the atomizing nozzle exit opening

Figure 3-2 CFD prediction of the radial distribution of the axial velocity at three distances from the nozzle face. For comparison with Figure 2-4 . . . . . . . 3-2

Figure 3-3 CFD simulation of combustion chamber flowfield. Cold (non-combusting)

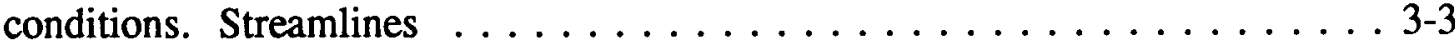

Figure 3-4 CFD simulation of combustion chamber flowfield. Cold (non-combusting) conditions. Axial velocity in meters/second. Inside flame tube only . . . . . 3-3

Figure 3-5 General arrangement of flame tube for combustion testing . . . . . . . . . . 3-4

Figure 4-1 Results of parametric geometry tests. Burner firing into quartz cylinder combustion chamber. Firing rate 0.28 Gallons Per Hour. Excess air $15 \%$

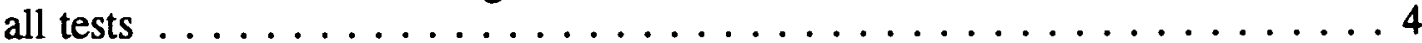

Figure $4-2$ Ignition electrode arrangement $\ldots \ldots \ldots \ldots \ldots \ldots \ldots \ldots$

Figure $4-3 \quad$ Ignition test zones $\ldots \ldots \ldots \ldots \ldots \ldots \ldots \ldots \ldots \ldots \ldots$

Figure 4-4 Illustration of the combustion chamber arrangement in two-section, cast iron boiler ............................. . . . . .

Figured $4-5$ General arrangement of steel boiler tested $\ldots \ldots \ldots \ldots \ldots \ldots$

Figure $4-6$ Illustration of up-flow warm air furnace $\ldots \ldots \ldots \ldots \ldots \ldots$

Figure 4-7 Up-flow warm air furnance.. Comparison of performance: conventional Retention head burner ( $0.5 \mathrm{gph})$; original Fan Atomized Burner (0.4 gph);

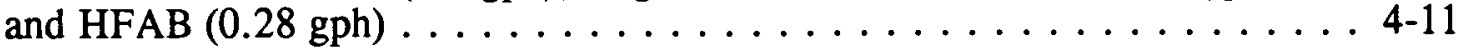

Figure 4-8 Illustration of warm air furnance with a return flow combustion chamber . . 4-13 


\section{List of Tables}

Page

Table 4-1 Results of Preliminary Combustion Tests in Quartz Cylinder Combustion Chamber at Firing Rate of 0.28 Gallons Per Hour . . . . . . . . . 4-1

Table 4-2 Results of Combustion Tests in Cast Iron Boiler at Firing Rate of 0.2 Gallons Per Hour . . . . . . . . . . . . . . 4-5

Table 4-3 Results of Combustion Tests in Cast Iron Boiler at Firing Rate

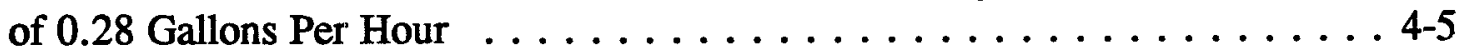

Table 4-4 Results of Combustion Tests in Steel Boiler at Firing Rate of 0.28 Gallons Per Hour $\ldots \ldots \ldots \ldots \ldots \ldots \ldots \ldots .7$

Table 4-5 Results of Combustion Tests in an Up-Flow Warm Air Furnace at Firing Rate of 0.28 Gallons Per Hour . . . . . . . . . . . 4-10

Table 4-6 Results of Combustion Tests in a Warm Air Furnace with a Return Flow Combustion Chamber at a Firing Rate of 0.28 Gallons Per Hour . . . . . 4 4-12 


\begin{abstract}
This report describes technical advances made to the concept of a low pressure, air atomized oil burner for home heating applications. Currently all oil burners on the market are of the pressure atomized, retention head type. These burners have a lower firing rate limit of about 0.5 gallons per hour of oil, due to reliability problems related to small flow passage sizes. High pressure air atomized burners have been shown to be one route to avoid this problem but air compressor cost and reliability have practically eliminated this approach. With the low pressure air atomized burner the air required for atomization can be provided by a fan at 5-8 inches of water pressure. A burner using this concept, termed the Fan-Atomized Burner or "FAB" has been developed and is currently being commercialized. In the head of the $\mathrm{FAB}$, the combustion air is divided into three parts, much like a conventional retention head burner. This report describes development work on a new concept in which $100 \%$ of the air from the fan goes through the atomizer. The primary advantage of this approach is a great simplification of the head design.
\end{abstract}

A nozzle specifically sized for this concept was built and is described in the report. Basic flow pressure tests, cold air velocity profiles, and atomization performance have been measured. A burner head / flame tube has been developed which promotes a torroidal recirculation zone near the nozzle for flame stability. The burner head has been tested in several furnace and boiler applications over the firing rate range 0.2 to 0.28 gallons per hour. In all cases the burner can operate with very low excess air levels (under 10\%) without producing smoke. Flue gas $\mathrm{NO}_{\mathrm{x}}$ concentration varied from 42 to $62 \mathrm{ppm}$ at $3 \% \mathrm{O}_{2}$. The concept is seen as having significant potential and planned development efforts are discussed. 


\section{INTRODUCTION}

Currently in the U.S. essentially all oil-fired burners for home space heating and domestic hot water service are of the pressure atomized, yellow flame, retention head type. In these burners fuel is delivered to a simplex atomizing nozzle at a regulated pressure ranging from 100 to $150 \mathrm{psi}$. In addition to atomizing the fuel the small, carefully controlled size of the nozzle exit orifice serves to control burner firing rate. The industry trend is to move toward the higher end of this range for improved atomization. Figure 1-1 shows an example of one burner head of this type. Combustion air is delivered under a pressure of 0.5 to 1.0 inches of water to the upstream side of the retention plate. As shown in the figure the air is divided into three parts flowing through the retention plate and into the combustion zone. Primary air flows through the center opening in the retention plate. Secondary air flows through radial slots in the retention plate and tertiary air flows through an annular area around the retention plate. The open area for primary and secondary air is fixed but the area for tertiary air can be adjusted by moving the retention head in and out. Generally, the tertiary air open area is adjusted to a preset position based on desired firing rate and the excess air is trimmed in the field by adjusting a damper at the fan inlet. With this design a single product can be used over a fairly wide firing rate range.

In Europe over half of the new burners sold currently are also of the yellow flame, retention head type. There are, in addition, numerous blue flame, low NOx burners on the market. These are characterized by head designs which promote the recirculation of combustion products into the early flame region. Combustion air velocity tends to be higher and, in many designs, concentrated more toward the central, primary air [1].

An important limitation of the pressure atomized burner, either with yellow or blue flame is an inability to operate reliably at firing rates under about 0.5 gallons per hour. This has been an impediment to the development of high efficiency, oil-fired appliances which can be well matched to some loads. There are numerous low-input gas-fired appliances now on the market. Oil atomization nozzles have been made for lower firing rates but experience has shown that such nozzles suffer rapid fouling of the small passages required, leading to bad spray patterns and poor combustion performance.

A number of interesting designs for achieving low inputs with oil have been developed to varying degrees, some as part of the BNL Combustion Equipment Technology Program. Air atomization, blue flame (recirculating), and prevaporizing burners have received attention. An excellent review of prior work in this area was published in 1980 [2]. Some of the more recent work in advanced burners has been described in the proceedings of the annual BNL Oil Heat Conferences. In 1990, a study was completed in which the emissions performance of conventional and advanced burners were compared [3]. This study included air atomization and prevaporizing burners. General options for atomizers for advanced burners were also reviewed [4]. Replacing the pressure atomizing nozzle with an air atomizing nozzle eliminates the small passages. These systems require the integration of a small compressor, however, which increases system cost and complexity. More recently, pulsed oil in pressure atomized systems has been receiving attention as a practical method of achieving low 


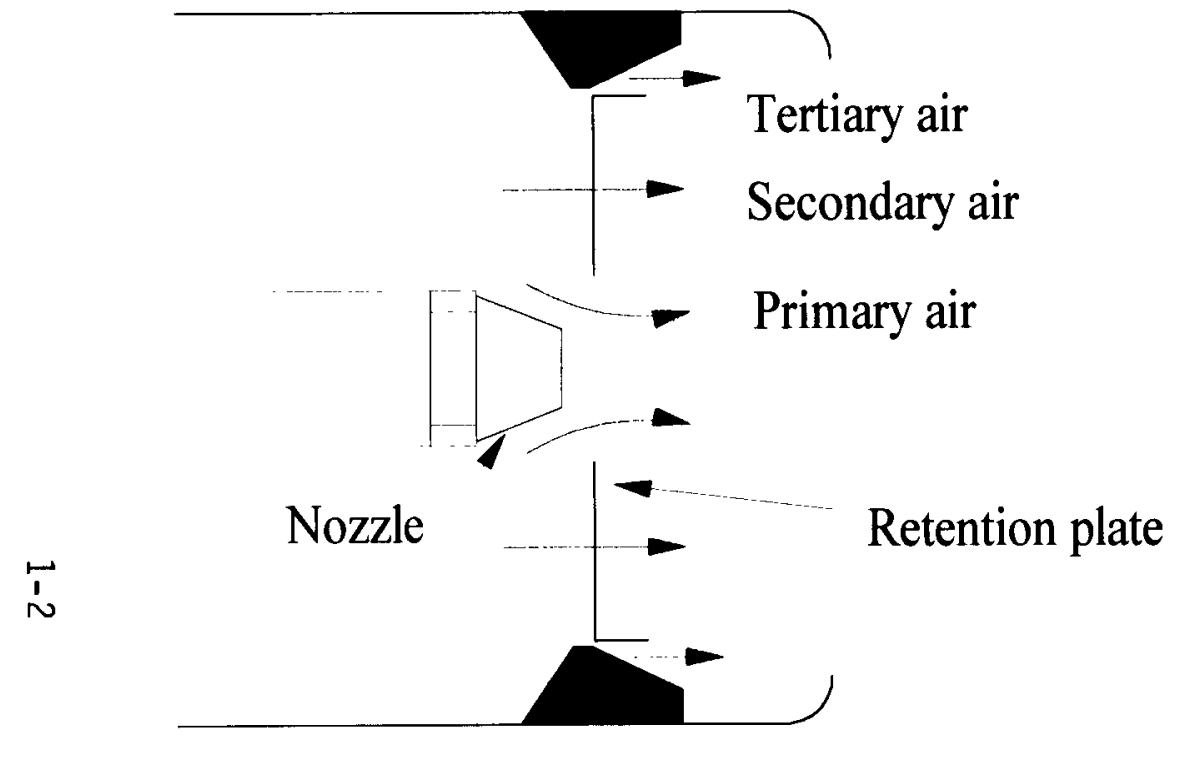

$\underline{\text { SIDE VIEW }}$

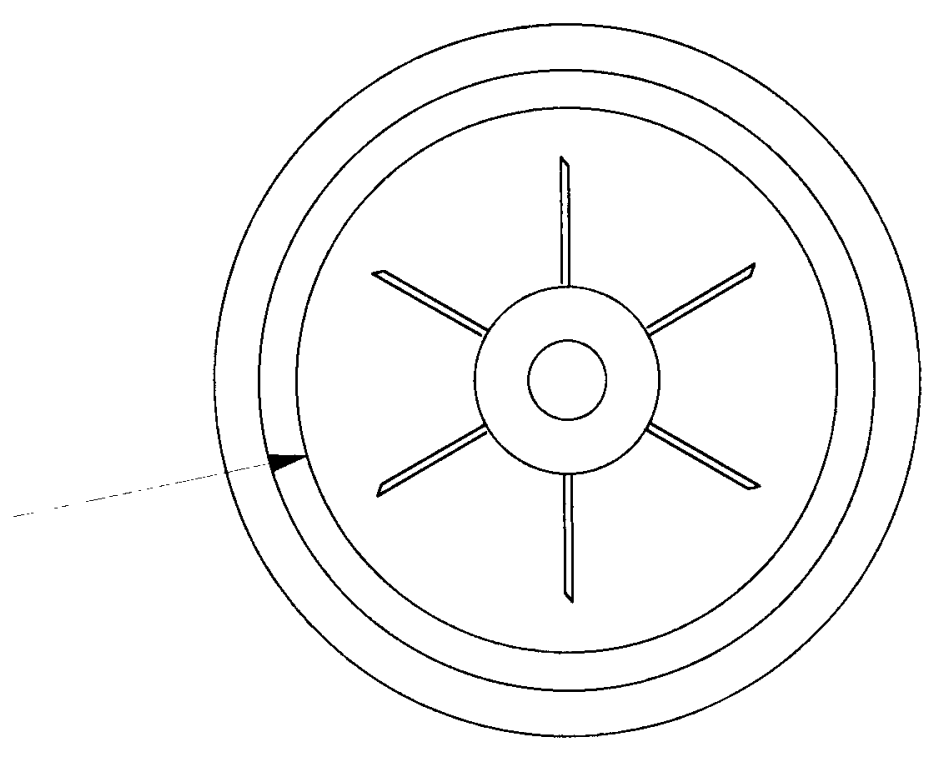

FRONT VIEW

Figure 1-1. Illustration of air distribution around the head of a conventional, pressure-atomized retention head burner. 
firing rates [5]. This approach is reportedly applicable only to blue flame systems where the high rates of internal recirculation can damped the effects of the periodic oil injection rate [6].

In prior work at BNL an approach toward achieving low firing rates has been developed which has become termed the Fan-Atomized Burner or "FAB". Here, fuel oil is atomized with air supplied by the burner's fan. There is only one air supply in this burner - a fan delivering air at a pressure of about 6 inches of water. The nozzle used is a prefilming airblast atomizer of the type very commonly used in gas turbine combustors [7]. A considerable amount of development work was done on this concept at BNL [8] and it is now being commercialized by Heat Wise, Inc. of New York [9]. As of the present time the burner has received approval by Underwriters Laboratory and an extensive field test is starting.

Figure 1-2 shows the air flow distribution at the head of the FAB burner. The arrangement is similar in some important ways to the air flow distribution in a conventional, pressure atomized retention head burner. All of the combustion air is fed into the back end of the air tube and is divided into three parts at the head. Primary air enters the nozzle and is used to atomize the fuel. Secondary air flows through swirl slots in the retention plate and tertiary air flows through an adjustable annular opening around the retention plate. As in the case of the common pressure atomizer this arrangement provides flexibility to operate over a range of firing rates. This burner nominally can be used over the range 0.35 to 0.65 gallons per hour.

This report describes the results of work aimed at the development of a new burner head arrangement using the low pressure air atomized, residential oil burner concept. In this approach $100 \%$ of the combustion air is directed through the atomizer. Expected benefits of this new arrangement, which led to initiation of this development effort include:

- improved atomization with higher atomizer flows

- a simpler, lower cost burner head

- lower NOx emissions.

From the start this design approach also carried several negative features or design challenges. These include:

- a limited firing rate range for each nozzle

- potential for reduced flame stability.

On atomization there have been several studies in which atomization performance of airblast nozzles have been correlated with fluid properties and operating conditions. With constant air velocity and other parameters also fixed, spray mean drop size decreases consistently with increasing atomizer air/fuel ratio [7].

With this design approach the burner head is expected to be simpler as the secondary and tertiary air flows are eliminated. In the FAB the tertiary air annular opening is small, particularly at low firing rates. Small differences in the opening size around the annulus can lead to non-optimum air 
distribution and performance. With the new approach presented here this criticality is simply eliminated.

With the use of $100 \%$ of the combustion air flow through the nozzle the flow in the flame zone is essentially a single, swirling jet with higher velocities than earlier designs. This arrangement provides great opportunity to recirculate combustion product to the root of the flame. The higher velocities can drive very high recirculation rates, leading to lower peak flame temperatures and reduced NOx.

The limited firing rate range results from elimination of the variable annular tertiary air flow area. With all of the air flowing through the nozzle the air mass flow rate can only be varied by changing atomizing air pressure and flow varies as $\mathrm{P}^{1 / 2}$. The upper limit on air pressure is set by the fan characteristics, noise, and flame stability. At the low pressure end, reduced air velocity through the atomizer leads to poor atomization quality. Practically, with this approach the firing rate can only be varied over a small range. As with conventional, pressure atomized burners a nozzle change would be required for a firing rate change.

In a conventional burner, and the $\mathrm{FAB}$, the presence of a rich fuel air mixture at moderate velocities behind the retention plate leads to excellent ignition characteristics. With the approach of $100 \%$ air through the nozzle the mixture is everywhere at least slightly lean and velocities are considerably higher. This leads to the potential for reduced flame stability [10].

In Section 2 of this report the nozzle built and tested in this program is described along with the predicted swirl number and velocity profiles at the nozzle exit as well as results of basic nozzle performance tests. Performance here includes the flow/pressure characteristics, axial velocity field downstream of the nozzle exit under non-combusting conditions, drop size distributions, and angular distribution of fuel in the spray. In Section 3 the development of a flame tube and burner head for use with this nozzle is presented. Section 4 includes results of combustion tests in a range of home heating appliances. Conclusions from this work as well as planned future work are presented in Section 5 . 


\section{CHARACTERISTICS OF THE ATOMIZING NOZZLE}

\subsection{Description of the Nozzle}

Figure 2-1 shows the principle of operation of the nozzle used in this work and Figure 2-2 is a photo showing the parts of the nozzle. In this configuration $100 \%$ of the combustion air, at a pressure of 4 to 6 inches of water enters the back of the nozzle body. Most of the air passes through the outer swirler and spins out through the main exit orifice. A smaller amount passes radially inward through four, small offset holes ("A" in Figure 2-1) providing counter swirling air around the pintle. Fuel entering at the centerline flows radially out through three small holes near the pintle tip where the swirling air distributes and swirls the oil, prefilming it as it leaves the inner orifice ("B" in Figure 2-1). The two counterswirling air flows shear the sheets and ligaments of fuel into a conical spray.

\subsection{Experimental Methods Used in Nozzle Characterization}

Measurements made for the purpose of characterizing the nozzle included:

- air flow rate as a function of air pressure,

- $\quad$ radial air velocity profile downstream of the nozzle,

- $\quad$ spray drop size as a function of air pressure and oil flow rate,

- angular distribution of oil in the spray.

For the first measurement air flow was simply measured using a calibrated orifice meter. The radial air velocity measurements were made without oil flow through the nozzle and a simple pitot tube was used. Spray drop size distributions were made using a commercial sizer (Malvern Scientific Instruments Corp.) based on Fraunhofer diffraction. Additional experimental details on the atomization system can be found in Reference 4 . To measure the angular distribution of fuel in the spray a row of square cross section containers was placed across the entire spray at an axial distance of 6.375 inches from the nozzle. Each container was $12.5 \mathrm{~mm}$ on each side and a total of 48 were included in the row. The mass of each container was measured before and after a 3 minute spray period.

\subsection{Results of Characterization Tests}

Figure 2-3 shows the basic flow pressure characteristics of the nozzle and this covers the range of air pressures considered to be practical for this application. In the development of the FAB burner discussed in the previous section considerable effort was put into fan selection. For reasons of system configuration, compatibility with conventional components, and cost the most attractive commercial burner package would use a conventional AC motor (eg. PSC). Without using very large diameters on the fan rotor, the pressures are practically limited to under about 8 inches of water. DC motors can achieve higher speeds and pressures and are an obvious alternative. There are many options with DC drive blowers and these have been used in much of the development work presented in this report. They are not currently being considered, however, for a commercial burner. 


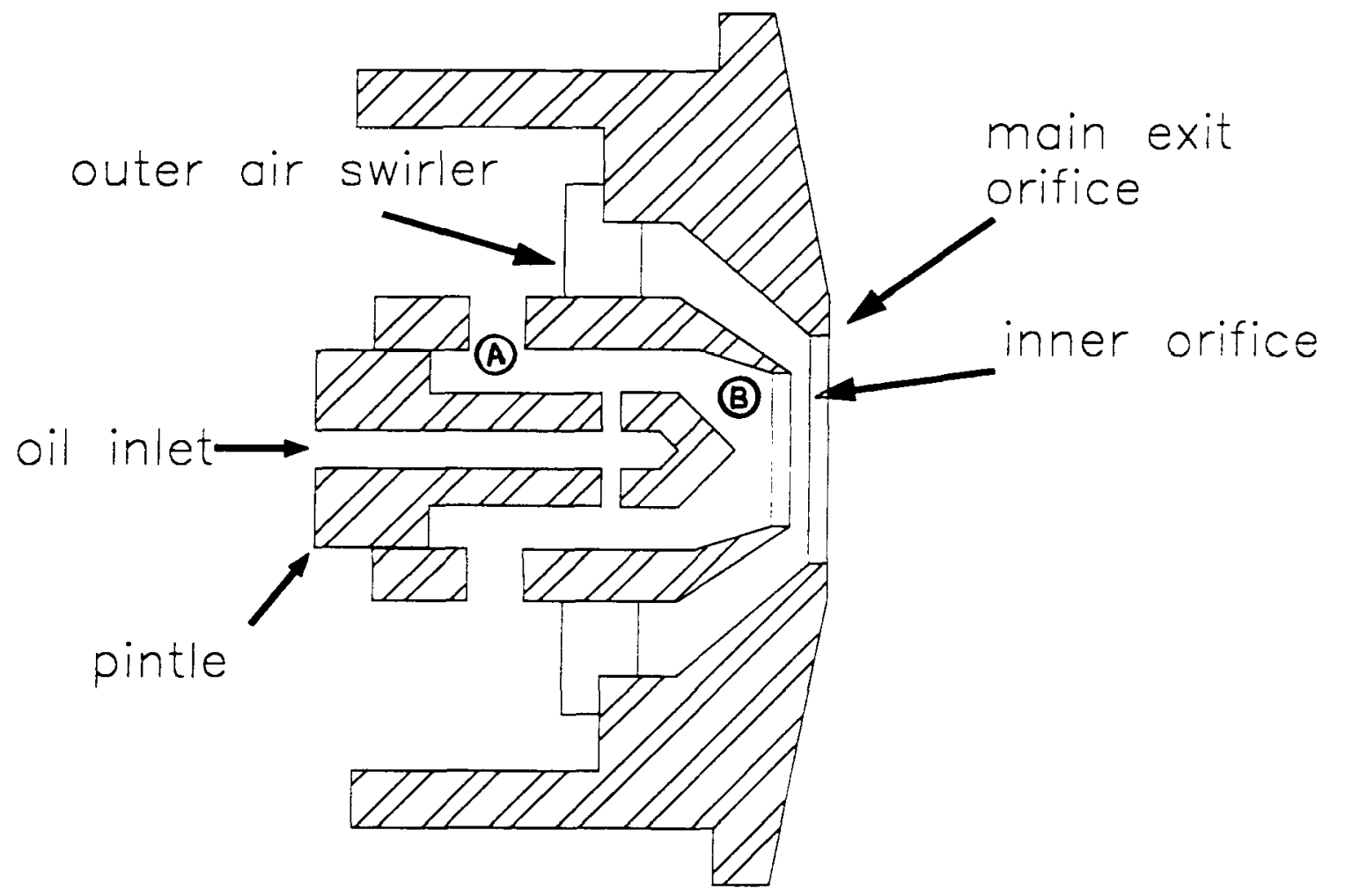

Figure 2-1. General illustration of the low-pressure, air atomizing nozzle showing air and fuel flow passages.
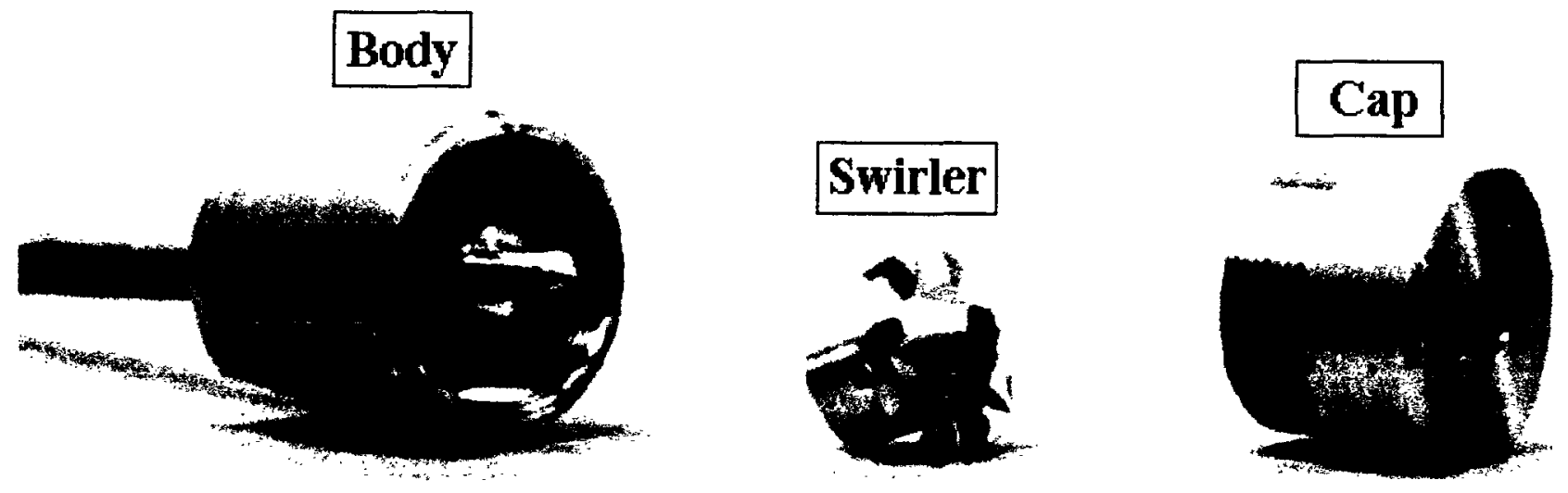

Figure 2-2. Photo illustration of nozzle components 
An air flow of $7 \mathrm{cfm}$ provides sufficient air flow for a firing rate of 0.25 gallons per hour with $20 \%$ excess air. This sets an upper limit on the firing rate for this nozzle and all combustion tests described in this report were done at low input rates. For larger rates a larger nozzle would obviously be necessary.

Results of the measurements of cold air radial velocity profiles produced by the nozzle are shown in Figure 2-4. These were measured with an unenclosed nozzle. The profiles are generally typical of those produced by a free jet with swirl [11]. Swirl flows are often characterized by the swirl number. This is a dimensionless group defined as the ratio of the axial flux of angular momentum to the product of a linear dimension (radius of nozzle opening) and the axial thrust. A swirl number of less than 0.6 is considered to be weak swirl. Over 0.6 a strong central recirculation zone forms. This central recirculation zone can be very important in stabilizing the flame.

The swirl number can be calculated as:

$$
S=\frac{G_{\varphi}}{G_{x} R}
$$

where:

$$
\begin{aligned}
& \mathrm{G}_{\varphi}=\text { axial flux of angular momentum } \\
& \mathrm{G}_{\mathrm{x}}=\text { axial thrust } \\
& \mathrm{R}=\text { radius of nozzle exit opening }
\end{aligned}
$$

For given radial profiles of axial velocity, tangential velocity, and pressure these can be calculated as:

$$
\begin{aligned}
& G_{\varphi}=\int_{0}^{R} W r \rho U 2 \pi r d r \\
& G_{x}=\int_{0}^{R} U \rho U 2 \pi r d r+\int_{0}^{R} p 2 \pi r d r
\end{aligned}
$$

where:

$$
\begin{aligned}
& U=\text { axial velocity } \\
& W=\text { tangential velocity } \\
& p=\text { pressure } \\
& \rho=\text { density }
\end{aligned}
$$

These velocities are illustrated below. 


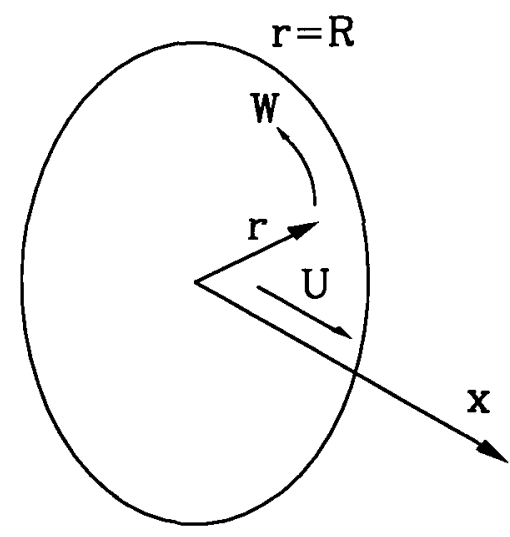

Illustration of axial and tangential velocity components across the exit opening of the nozzle.

Estimates of the swirl number for the nozzle used in this program were made using the internal geometry and swirler vane angles [11]. Based on these the swirl number is in the 0.3 to 0.4 range. The important implication of this is that the flame would need to be stablilized with an external rather than an internal recirculation zone. The measured velocity profiles, however, do indicate the presence of a small internal recirculation zone close to the nozzle. This point is discussed further in the next section.

Results of atomization tests over a very wide range of oil flow rates are shown in Figure 2-5. These basically indicate excellent atomization. Typically, for the common pressure atomized nozzles the spray mass mean diameter is about $30-40$ microns [12].

Figure 2-6 shows the results of tests to evaluate the spray pattern. The spray field shows a solid core and total spray angle of about $80^{\circ}$. 


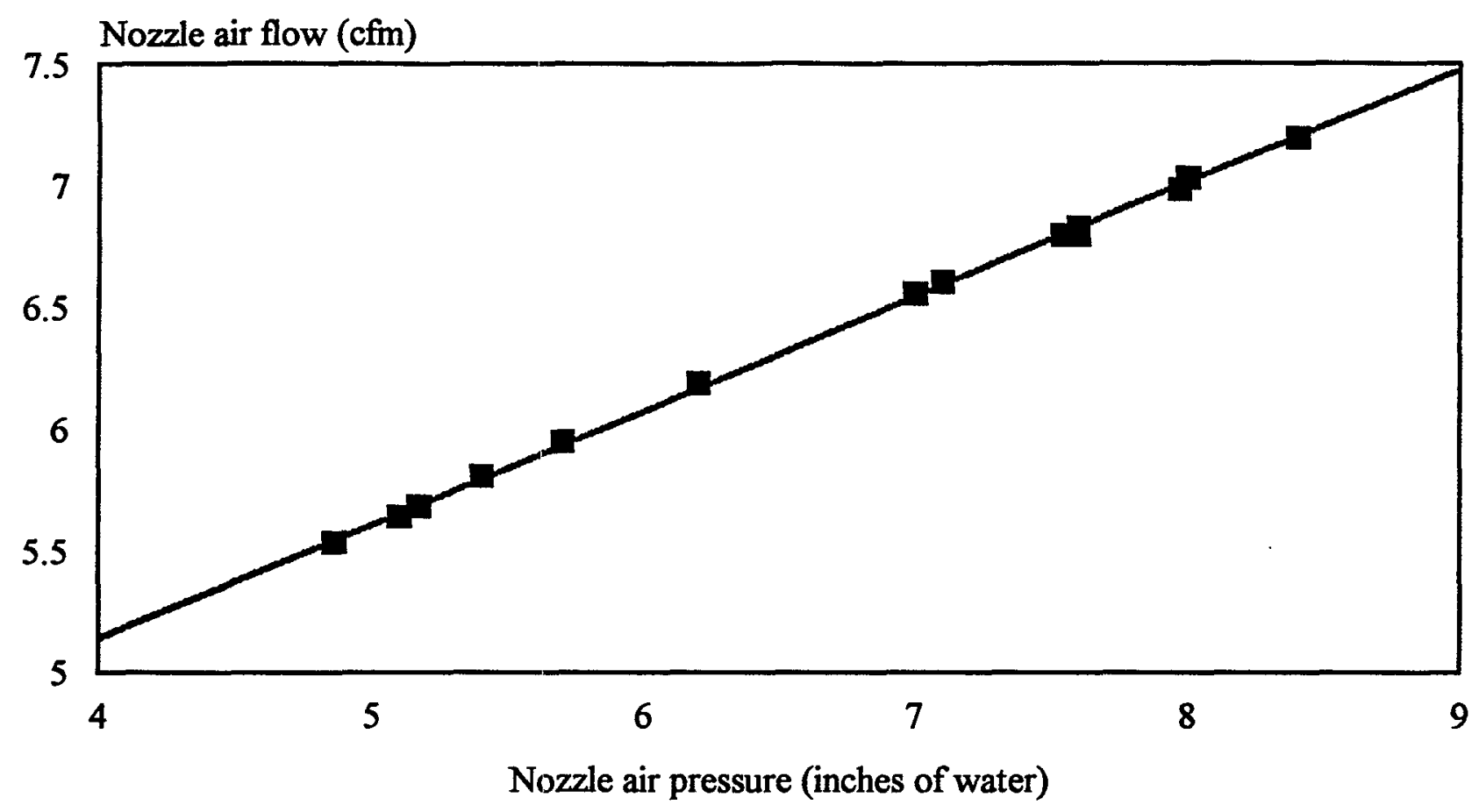

Figure 2-3. Basic flow/pressure relationship for atomizing nozzle.

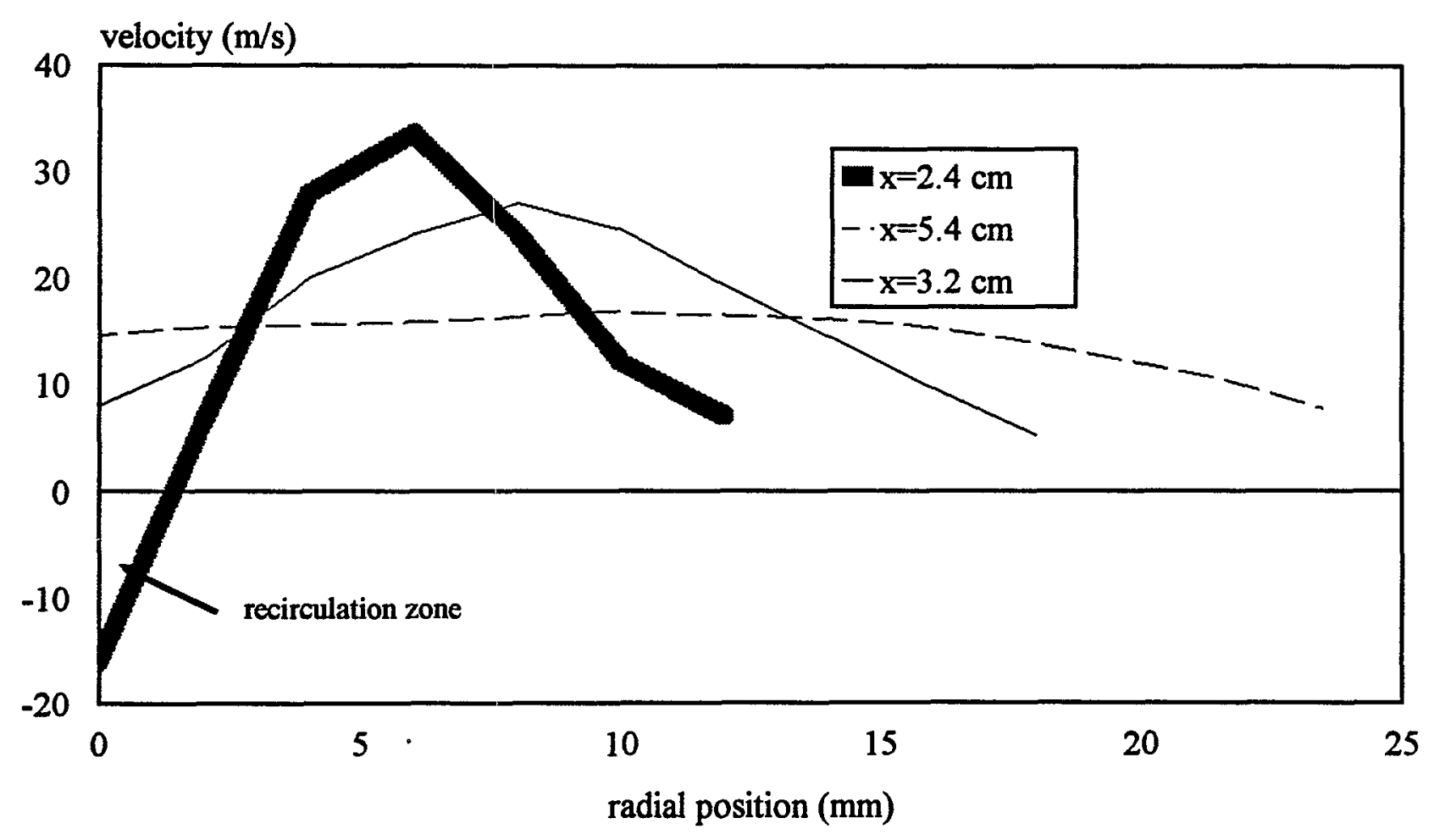

Figure 2-4. Radial profiles of axial velocity at three axial distance from nozzle face. Air pressure $=9$ inches of water. 


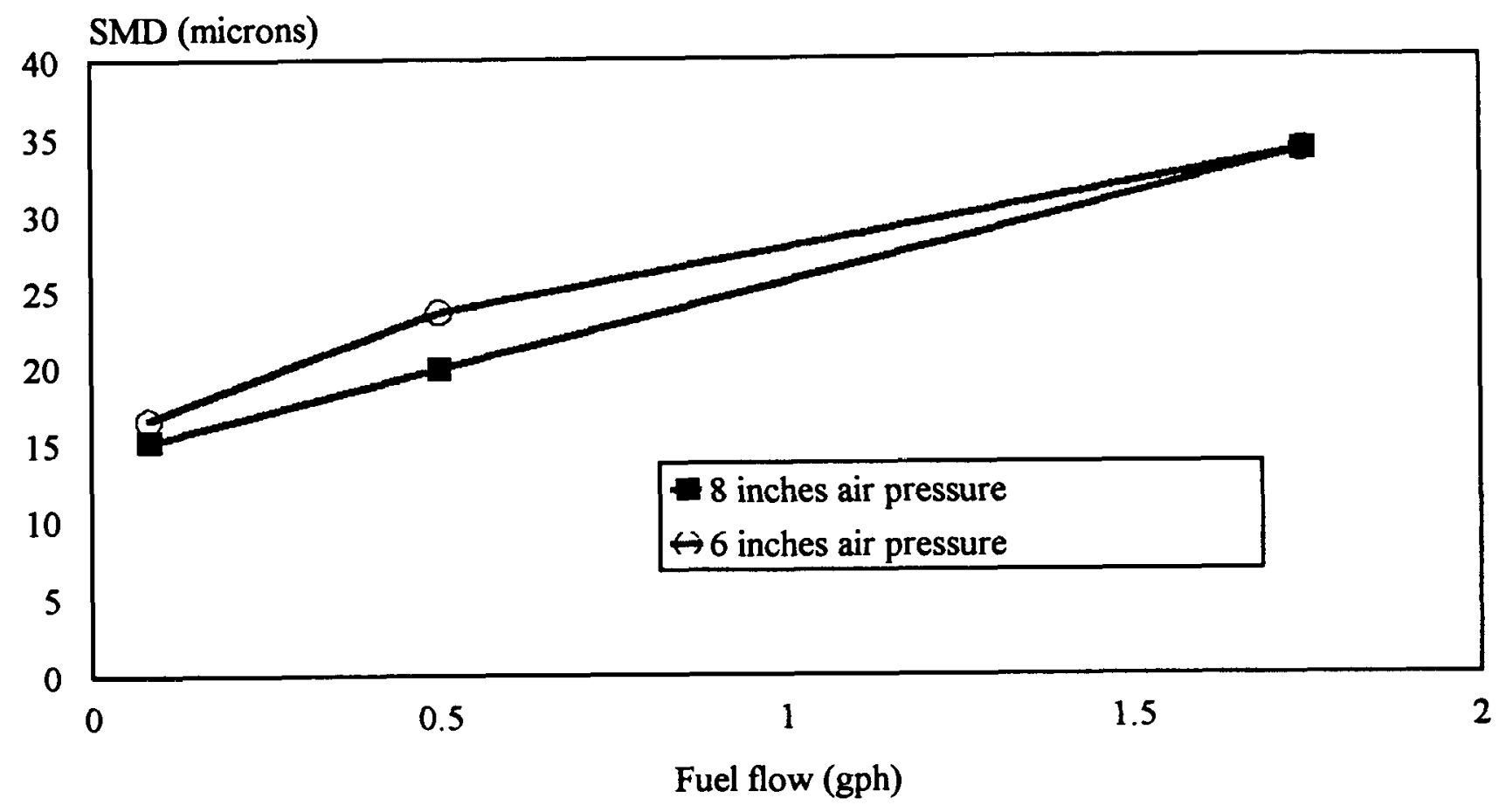

Figure 2-5. Results of atomization tests with nozzle at 6 and 8 inches of air pressure. 


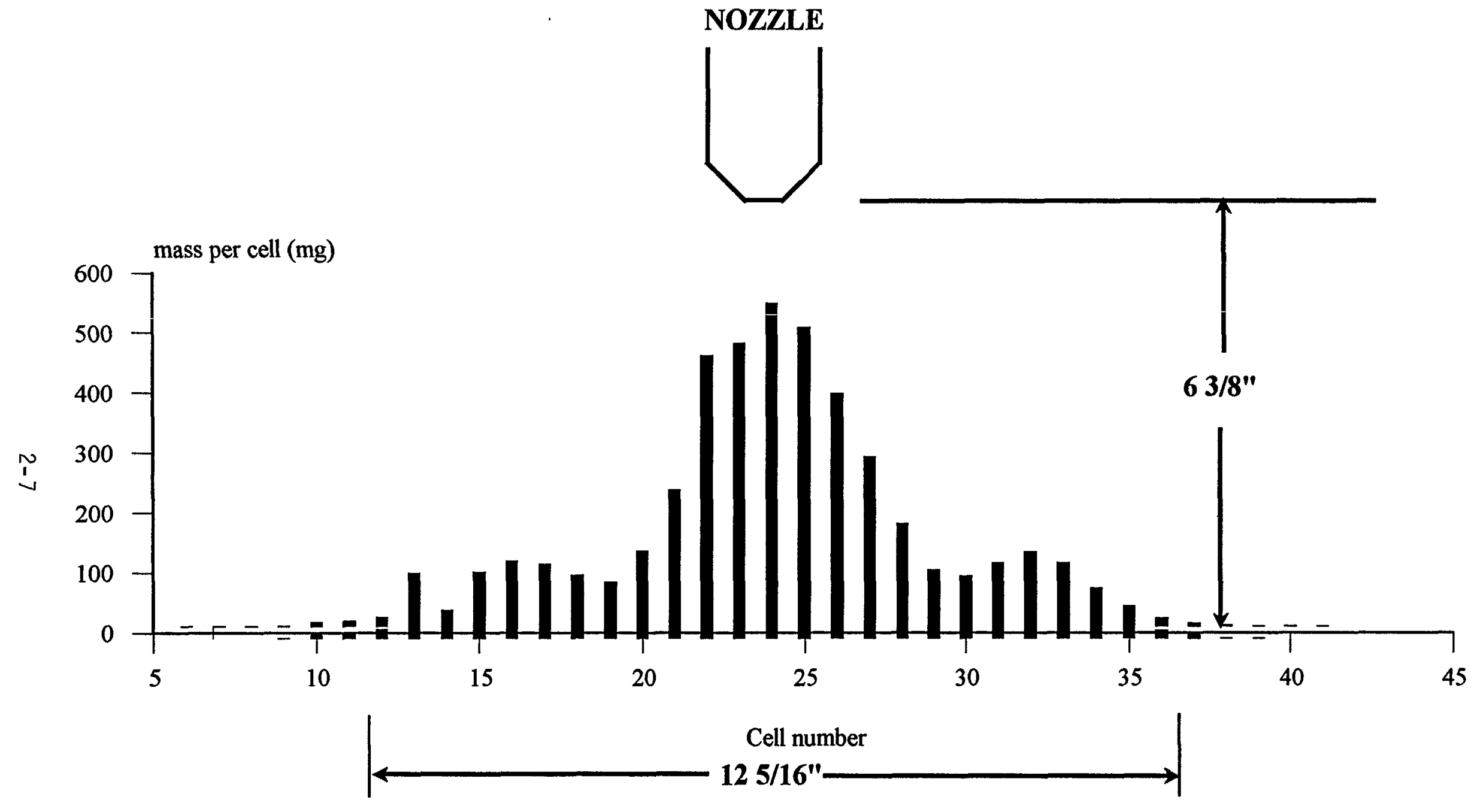

Figure 2-6. Results of spray pattern test with nozzle. Air pressure $=8$ inches of water. Oil flow $=0.5$ gallons-per-hour 


\section{BURNER HEAD DESIGN}

In planning burner heads the general objectives are to give enough internal recirculation near the root of the flame to produce good stability over a wide range of excess air levels, to locate the ignition source in a position which gives reliable startups, to avoid coke formation on surfaces, to allow for recirculation of cooler combustion products into the flame zone for NOx control, and, of course, to have low $\mathrm{CO}$ and smoke emissions particularly at low excess air levels.

To assist in the planning of a burner head a 2-dimensional Computational Fluid Dynamics (CFD) computer program was used to study the air flow patterns under non-combusting conditions. The program used was "Compact" from Innovative Research Inc. This is a control volume type program. For turbulence modeling the common $k-\epsilon$ method was used.

In modeling of the air flow around the burner head it is convenient to start with the air flow from the exit of the atomizing nozzle as a boundary condition. In initial CFD simulations an assumption was made that the axial velocity and angular velocity were uniform across the cross section of the 0.438 inch diameter nozzle exit opening. 'This assumption, however, was found to produce axial velocity profiles a short distance downstream from the nozzle considerably different from those measured (see Figure 2-4). For this reason some initial simulations were done of flow inside of the nozzle only for the purpose of allowing improved estimates of the boundary conditions for the downstream simulations. In the internal 2-D simulations the flow from the slotted swirler was replaced by a uniform swirling flow as a boundary condition. Results of this simulation are shown in Figure 3-1 and these are the results used as boundary conditions in downstream simulations. Figure 3-2 shows the axial velocity profiles at three downstream distances from the nozzle exit orifice. For this simulation the nozzle was placed in the center of the end wall of a large, cylindrical enclosure. These profiles can be compared with velocity profiles measured under cold flow conditions - see Figure 2-4.

The general arrangement planned for the combustion testing involved adding a cylindrical flame tube in front of the nozzle. For this arrangement cold flow CFD studies were done to evaluate flow patterns. Results of this are shown in Figures 3-3 and 3-4 including the streamlines and axial velocity fields respectively. On the axis of the flame tube there is a strong forward velocity within the expanding jet flow from the nozzle. Around this central jet flow there is an annular zone of reverse flow. As Figures 3-3 and 3-4 show, with this arrangement the reverse flow which supplies the entrainment of the expanding jet comes from relatively far out in the combustion chamber. The recirculation of this gas, which would be considerably cooler than the peak flame temperature, would reduce NOx emissions but can also contribute to reduced flame stability. As a method of controlling the rate of recirculation of this relatively cool gas a choke plate was planned at the end of the flame tube. The size of this plate can be varied to change the relative rate of recirculation of hot gas from within the flame zone and cooler gas from farther out in the combustion chamber. The situation is simply illustrated in Figure 3-5. 


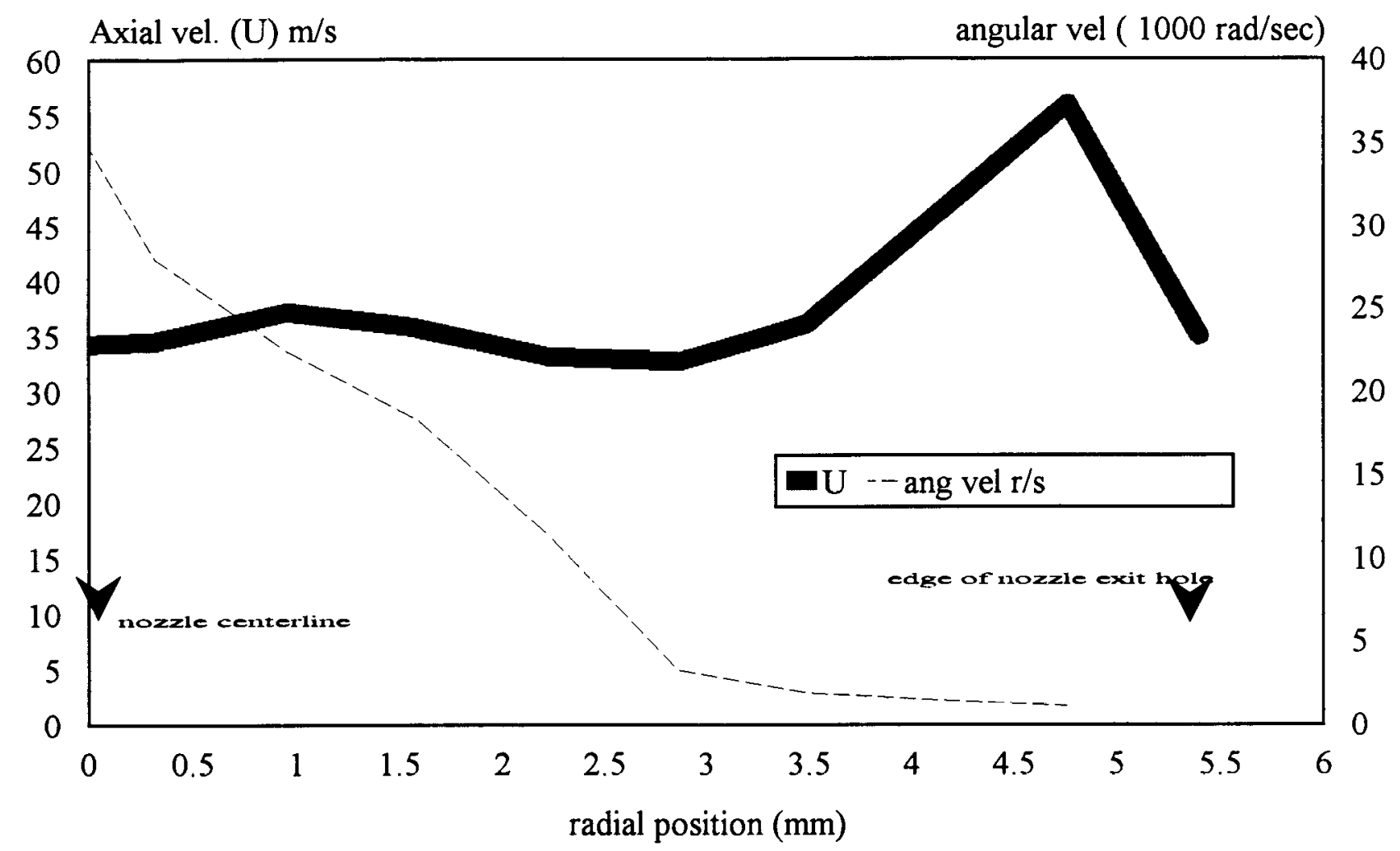

Figure 3-1. CFD predicition of the radial distribution of the axial velocity and the angular velocity at the atomizing nozzle exit opening.

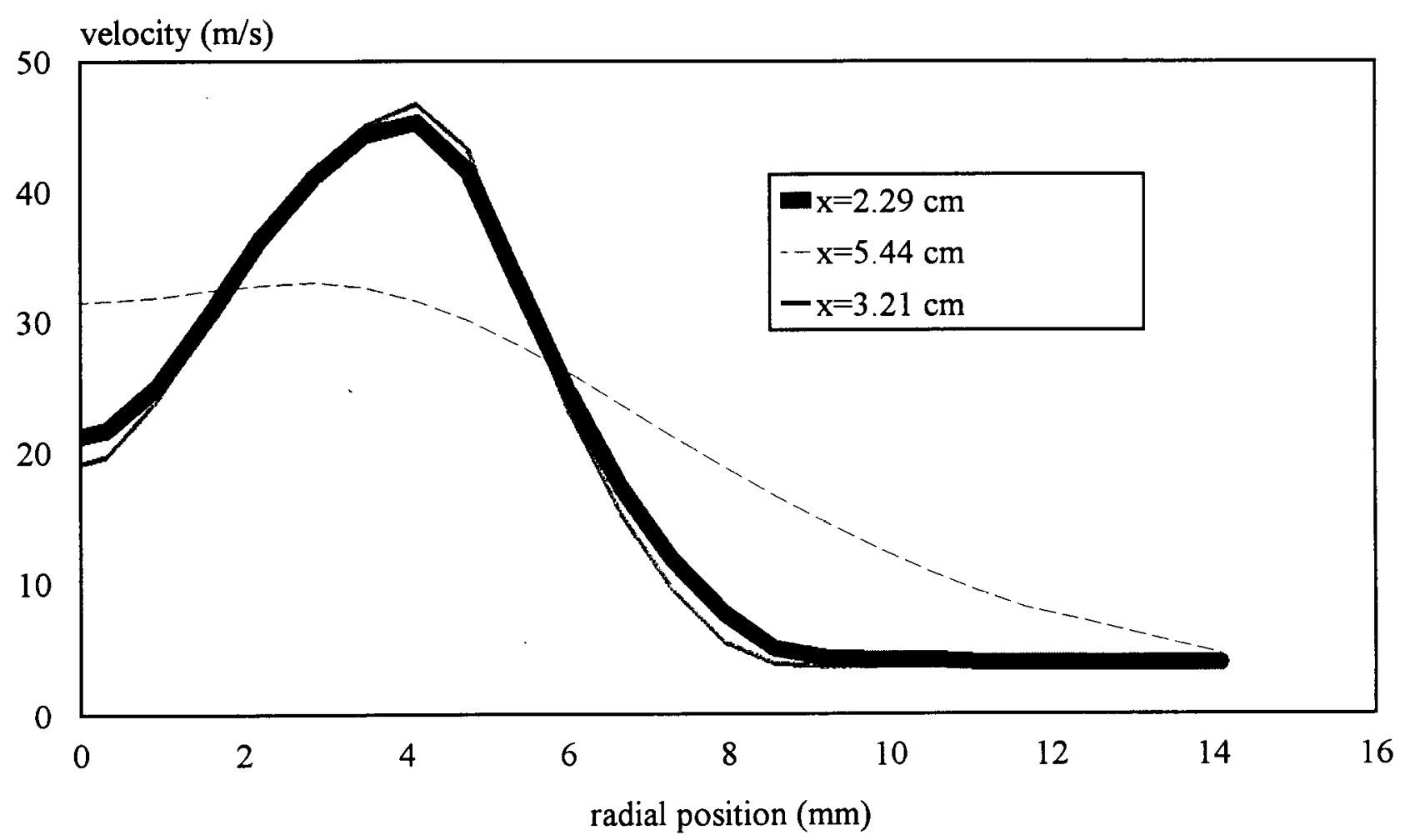

Figure 3-2. CFD predicition of the radial distribution of the axial velocity at three distances from the nozzle face. For comparison with Figure 2-4. 


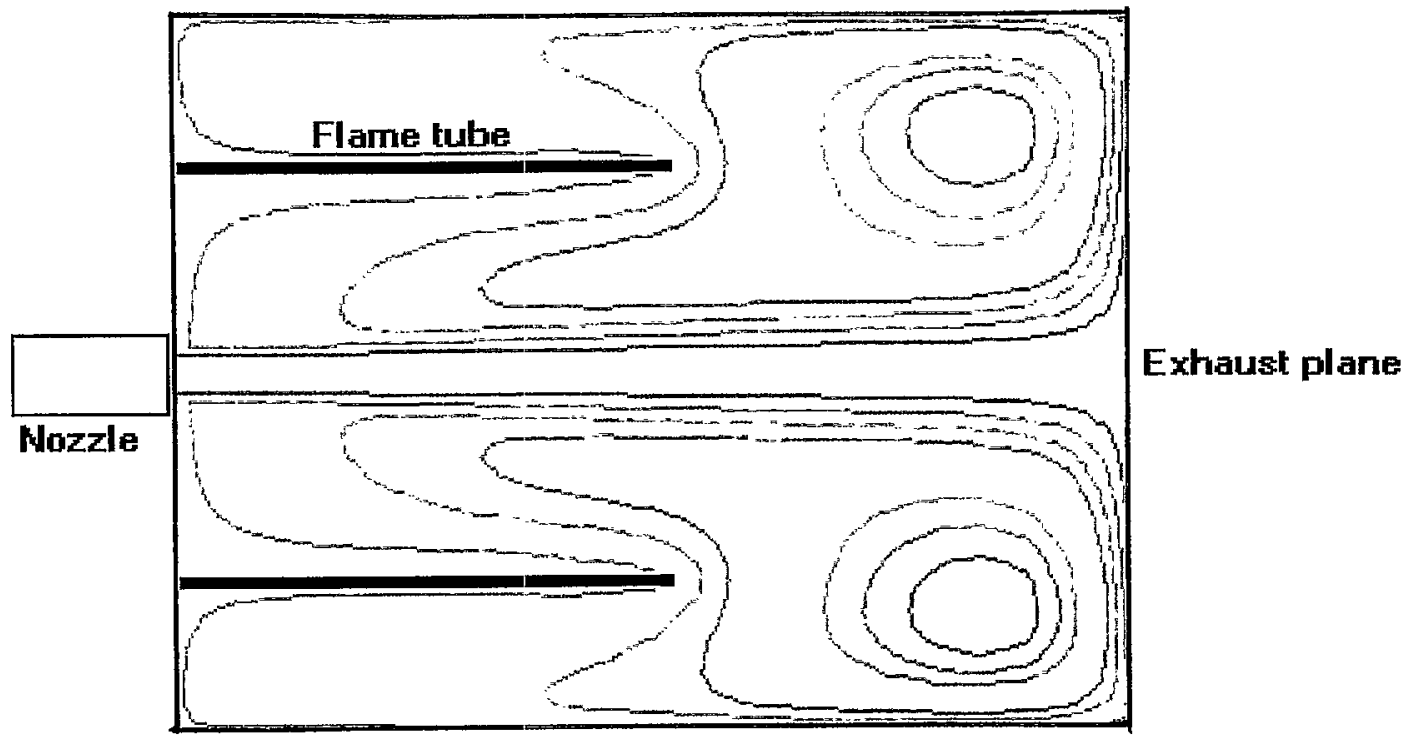

Figure 3-3. CFD simulation of combustion chamber flowfield. Cold (non-combusting) conditions. Streamlines.

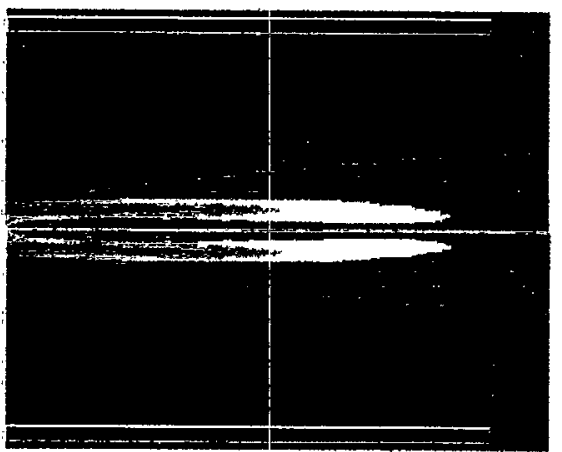

Axial Velocity Scale

\begin{tabular}{|c|c|c|}
\hline 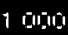 & $\because+$ & 5 50HE +1.1 \\
\hline Brin: & & 4 S5+E+1\% \\
\hline 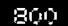 & & $4=09 E+11$ \\
\hline $7 \mathrm{Fin}^{2}$ & 5 & S GE: \\
\hline Bing & & $=17 E+i 1$ \\
\hline $5: 701$ & & $2: 71 E+111$ \\
\hline tiris & $=$ & 1 GEBE+11 \\
\hline 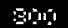 & En & G 7 \\
\hline$=121$ &.- & $B E 47 E+10$ \\
\hline 1 & & - Q $11 \mathrm{BE}+\mathrm{H}$ \\
\hline 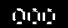 & & $-9574 E+10$ \\
\hline
\end{tabular}

Figure 3-4. CFD simulation of combustion chamber flowfield. Cold (non-combusting) conditions. Axial velocity in meters/second. Inside flame tube only. 


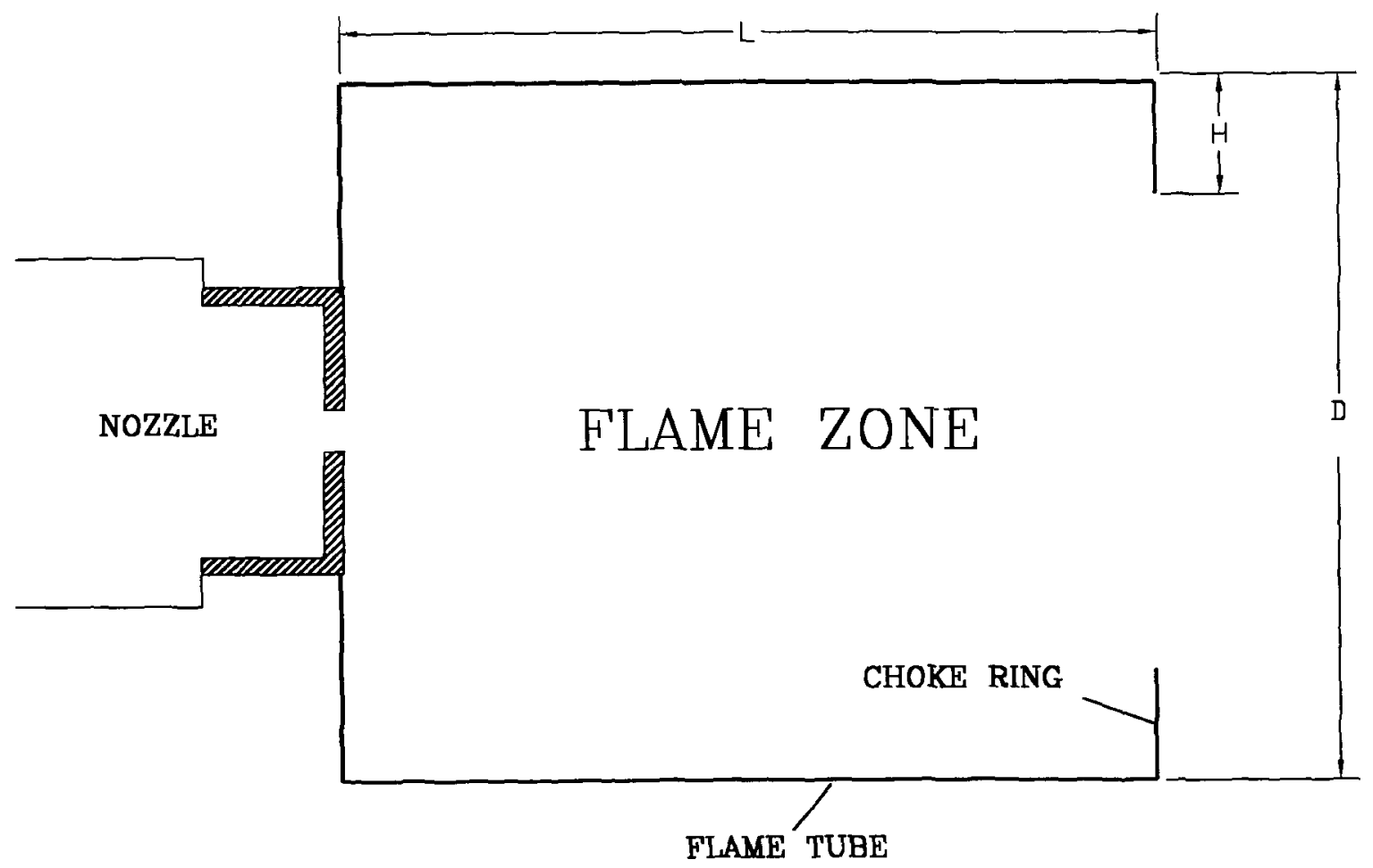

GIDLSKS \AUTOCAD.DTG BURNERA $5-203-07$

Figure 3-5. General arrangement of flame tube for combustion testing. 


\section{COMBUSTION PERFORMANCE}

\subsection{Characterization Tests in Quartz Combustion Chamber}

Initial combustion testing with the burner head was done using a quartz test chamber at BNL. The main part of this combustion chamber is a horizontal quartz cylinder with an inside diameter of 10 $1 / 2$ inches. The burner tested is installed at one end on the axis of the quartz cylinder and combustion products exhaust at the opposite end. The ends of the quartz cylinder are pressed into semi-soft refractory boards which effectively provide a seal. Steel plates at the front and rear ends hold the refractory boards rigid and tight against the quartz cylinder. The exhaust products are carried out using conventional flue piping and there is no heat recovery in the system resulting in very high exhaust gas temperatures $(1800 \mathrm{~F})$. A damper in the flue piping is adjusted during testing to provide a slight back pressure on the combustion chamber $(+0.01$ inches of water) to assure that air leakage into the combustion chamber which would affect performance and readings does not occur. Gas samples for analysis are extracted from the flue piping upstream of the damper. A simple stainless steel tube is used to extract gas samples from the flue piping. Addition details can be found in Reference 8.

For preliminary testing in the quartz cylinder the only objective was to evaluate flame stability and basic performance over a range of excess air levels. Test results are summarized in Table 4-1. The burner performed very well in these tests, producing low smoke, $\mathrm{CO}$, and NOx emissions over a very wide excess air range. For these tests the flame tube diameter was 3 inches, the flame tube length was 3 inches and the choke plate thickness was $3 / 8$ inches (" $D$ ", " $L$ ", and " $H$ " respectively in Figure 3-5). The firing rate during these tests was 0.28 gallons-per-hour.

Table 4-1. Results of Preliminary Combustion Tests in Quartz Cylinder Combustion Chamber at Firing Rate of 0.28 Gallons-Per-Hour.

\begin{tabular}{|r|r|r|r|r|r|r|}
\hline $\begin{array}{c}\text { Exhaust O2 } \\
(\%)\end{array}$ & $\begin{array}{c}\text { Excess air } \\
(\%)\end{array}$ & $\begin{array}{c}\text { Exhaust } \mathrm{CO}_{2}{ }^{1} \\
(\%)\end{array}$ & $\begin{array}{c}\mathrm{CO} \\
(\mathrm{ppm} \mathrm{@3 \% O2)}\end{array}$ & $\begin{array}{c}\text { NOx } \\
\text { (ppm @, 3\% O2) }\end{array}$ & Smoke Number & $\begin{array}{c}\text { Air Pressure } \\
\text { (inches of water) }\end{array}$ \\
\hline 0.55 & 2.5 & 15.2 & 22.9 & 46.7 & 0 & 6.1 \\
\hline 1.5 & 7.2 & 14.5 & 18.5 & 55.4 & 0 & 6.4 \\
\hline 2 & 9.8 & 14.1 & 18.0 & 58.7 & 0 & 6.8 \\
\hline 2.5 & 12.6 & 13.7 & 17.5 & 58.4 & 0 & 7.4 \\
\hline 2.9 & 15.0 & 13.4 & 17.9 & 57.7 & 0 & 7.7 \\
\hline 3.5 & 18.7 & 13.0 & 19.5 & 58.6 & 0 & 8.1 \\
\hline
\end{tabular}

1. calculated from measured exhaust gas oxygen.

During these combustion tests the flame was very stable and yellow in appearance. The color of the flame is an important consideration from a control perspective. Current residential oil burners have yellow flames and use inexpensive cadmium sulfide photocells for flame detection. The European low-NOx burners typically have blue flames and require more expensive infrared "flicker" detectors. In this burner effort it was considered desirable to have a yellow flame for cost and U.S. industry 
acceptance reasons. The NOx emission levels in this test are low compared with levels commonly found with oil-fired boilers in the U.S., 75 to $110 \mathrm{ppm}$, and with the levels currently considered to qualify as "low-NOx" in Europe - about 63 ppm.

In these initial tests the question of ignition was not addressed. The burner was simply lit with a torch and only steady state testing was done. Results of ignition studies are discussed below in Section 4.2.

The next series of tests involved parametric studies of the effects of flame tube length (" $L$ " in Figure 3-5) and size of the choke ring (" $\mathrm{H}$ " in Figure 3-5) on steady state performance. For these the excess air level and firing rate were fixed at $15 \%$ and 0.28 gallons-per-hour respectively. These tests were done with the burner firing into the quartz cylinder combustion chamber. Prior to these tests the flame tube diameter ("D" in Fig. 3-5) was increased from 3 inches to $31 / 2$ inches. This was done only to allow more room for fitting ignition electrodes and a flame view port in the future. Figure 4-1 shows the measured NOx emissions during these parametric tests. For all cases the CO emissions were low, on the order of $25 \mathrm{ppm}$, and the measured smoke number was 0 . From Figure

NOx@3\% O2 (ppm)

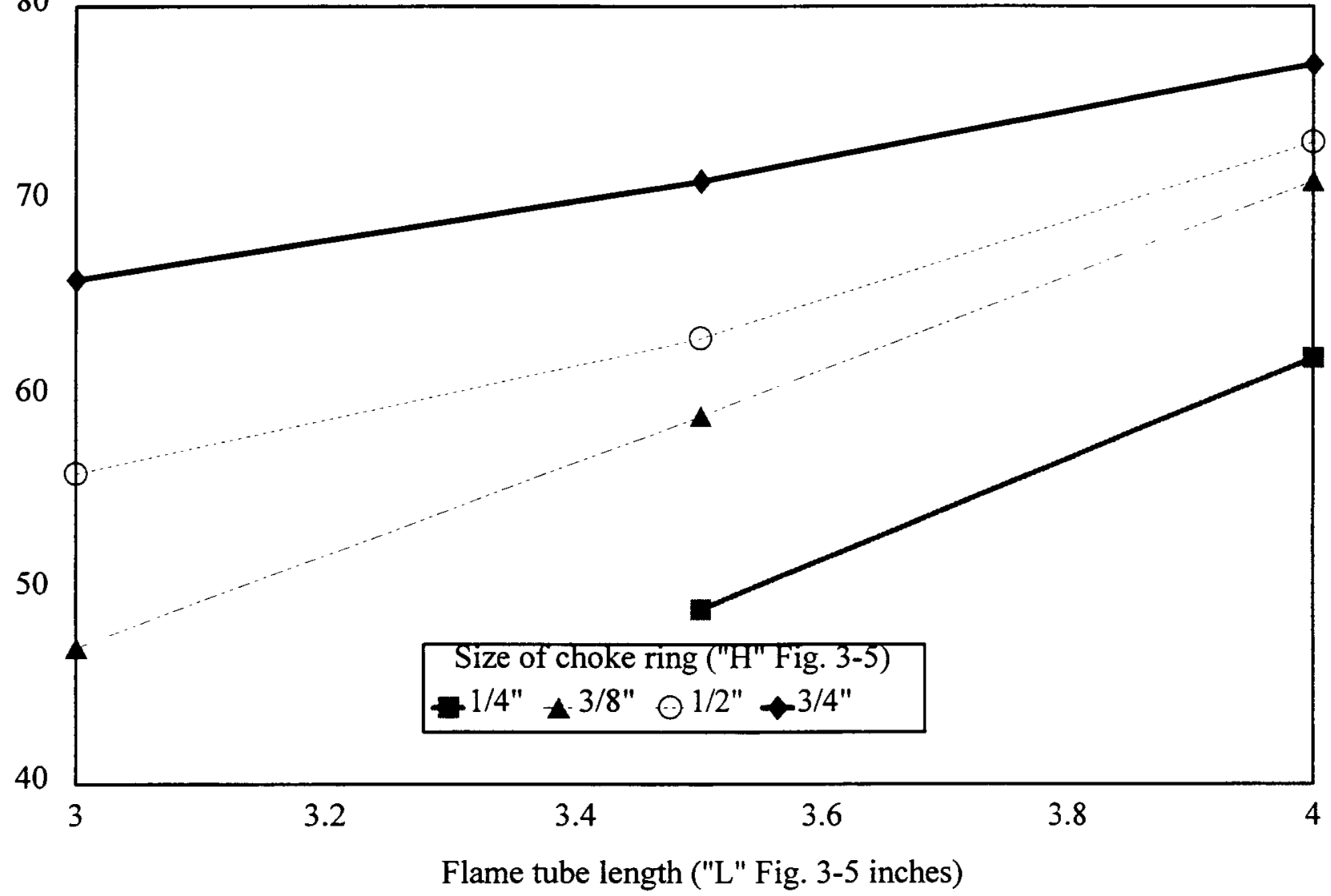

Figure 4-1. Results of parametric geometry tests. Burner firing into quartz cylinder combustion chamber. Firing rate 0.28 gallons-per-hour. Excess air $15 \%$ all tests 
implication is that decreasing either of these dimensions increases the rate of recirculation of combustion products from the outer part of the combustion chamber into the primary flame zone. From observations during the test, as NOx levels decrease the flame moves from yellow to "transparent" to blue in color. With a $1 / 4$ " choke ring and 3" flame tube length the flame could simply not be stabilized and this is consistent with excessive internal recirculation rates.

\subsection{Tests of Ignition Point Location}

In routine operation this burner will be ignited using a conventional, high voltage spark ignition system. A series of tests were done to plan placement of the ignition source and the basic arrangement is illustrated in Figure 4-2. In these tests the ignition point (end of electrodes) was positioned in different locations around the volume defined by the flame tube and the possibility and consistency of achieving ignition under cold conditions was evaluated.

The results of the ignition tests provide additional insights into the flow patterns within the flame tube. In Figure 4-3 the field is divided into four zones. Within zone I the flow direction is clearly back toward the nozzle. Here air and smaller drops are being drawn back to feed the entrainment of the expanding, swirling jet from the nozzle. Placing the ignition source in this area produced the best results.

In zone III the ignition spark is drawn into the expanding flow field from the nozzle. Here velocities are simply too high and consistant ignition was not achieved. Zone II is effectively between zones I and III. Here the spark is drawn back and toward the expanding central jet. Based on observation ignition is possible with the source located in this zone although ignition is not as consistent as in zone I. Zone IV represents an attempt to deliver the spark energy into the small recirculation zone on the axis. Tests in this location were not successful. Apparently, this central recirculation zone was simply too small. With the spark located here, the combustion air turned on, and the fuel turned off, a location in which the spark was drawn backwards toward the nozzle could not be found.

With the ignition source located in zone IV, consistent ignition was obtained at higher firing rates $(0.3$ gallons per hour) but not at lower rates. At the lower rates good ignition can be obtained by having an instantaneous "burst" of fuel at the moment the fuel is first opened. To do this the fuel system has a delayed opening fuel solenoid valve and a small accumulator volume between the pump and the solenoid valve.

\subsection{Combustion Tests in Selected Heating Appliances}

This section provides a summary of the results of combustion tests done in a variety of heating appliances. The units tested were selected based on their being common applications, appliances which are interesting for some specific feature, or appliances which are considered particularly well suited to this burner concept. For each unit tested a description of the combustion chamber configuration and a summary of the test results are provided below. 


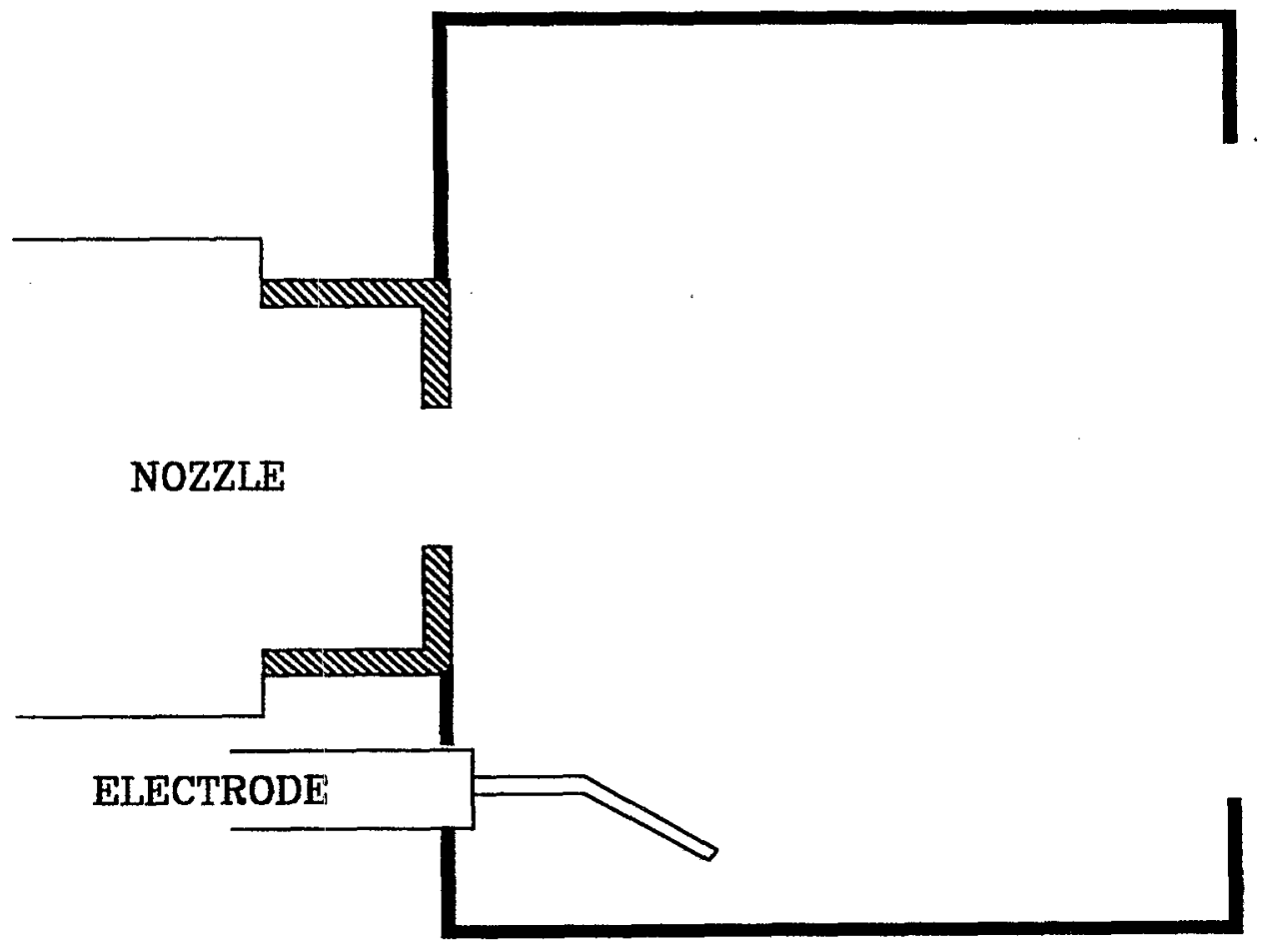

Figure 4-2. Ignition electrode arrangement

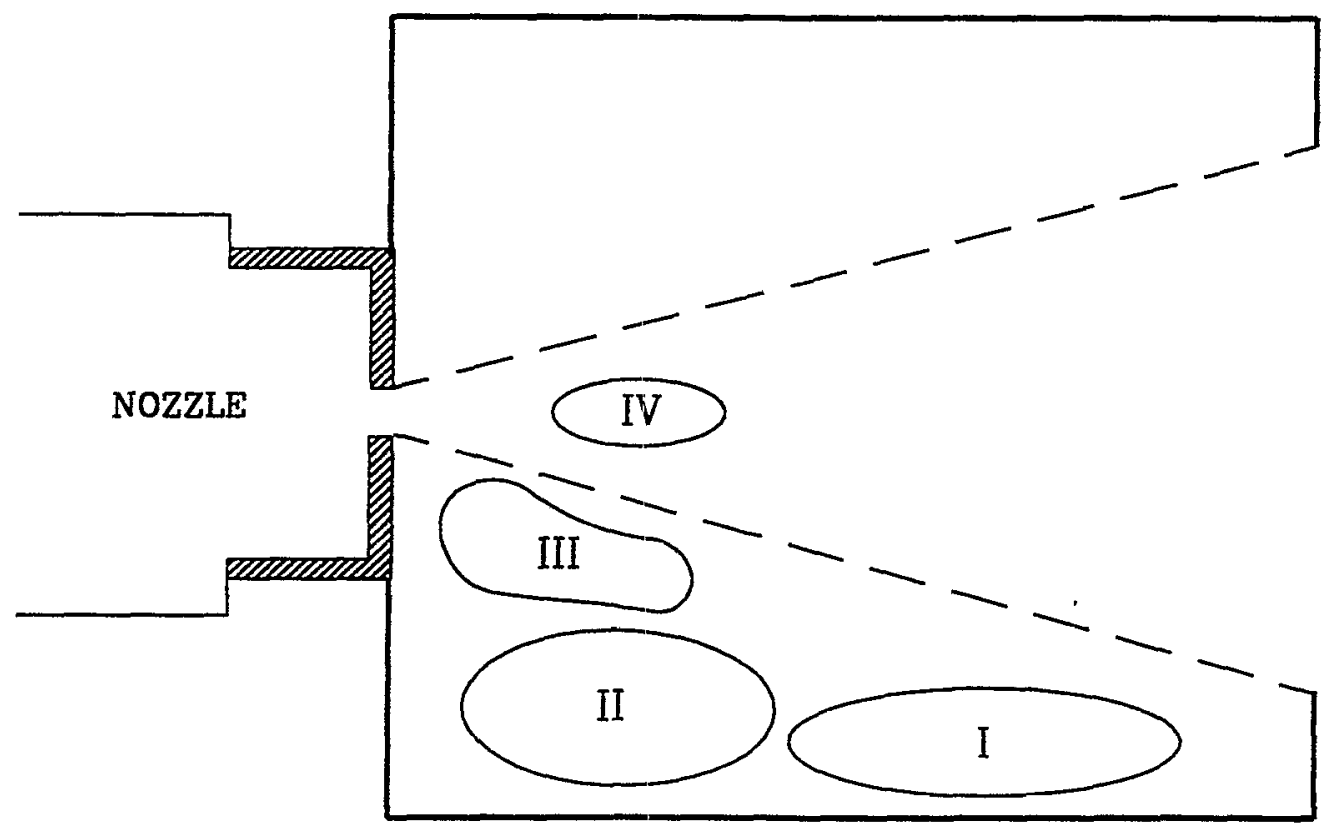

Figure 4-3. Ignition test zones 
Cast Iron Boiler -This boiler is a two section, wet-base, cast iron unit in the general form of a pin type vertical heat exchanger set above a nearly cube shaped combustion chamber. The configuration is illustrated in Figure 4-4. The combustion chamber contains a thick alumina-silica refractory front and a separate bowl-shaped refractory target wall. A refractory blanket bridges the bottom and sides of the exposed wet base. At the end of the chamber, the combustion gases are turned and forced to flow upward through the pin-type heat exchanger passage formed by the interface of the front and rear sections of the boiler. At the top the gases are turned $90^{\circ}$ within a rectangular collector passage and flow into a transitional breech connector to exit the rear of the boiler. All of the combustion gas handling components (exposed combustion chamber, flat and pined heat exchanger surfaces and lower portion of the breech connector passage) are cooled by the water flow used for space heating.

Tests with this boiler were completed at two firing rates, 0.20 and 0.29 gallons per hour. Table 4-2 provides a summary of performance at the lower rate and Table 4-3 provides a summary at the higher rate.

Table 4-2. Results of Combustion Tests in Cast Iron Boiler at Firing Rate of 0.2 gallons per hour.

\begin{tabular}{|r|r|r|r|r|r|r|}
\hline $\begin{array}{c}\text { Exhaust O2 } \\
(\%)\end{array}$ & \multicolumn{1}{c}{$\begin{array}{c}\text { Excess air } \\
\text { (\%) }\end{array}$} & $\begin{array}{c}\text { Exhaust } \mathrm{CO}_{2}{ }^{1} \\
(\%)\end{array}$ & $\begin{array}{c}\mathrm{CO} \\
(\mathrm{ppm} @ 3 \% \mathrm{O} 2)\end{array}$ & $\begin{array}{c}\text { NOx } \\
(\mathrm{ppm} @ 3 \% \\
\mathrm{O} 2)\end{array}$ & $\begin{array}{c}\text { Smoke Number } \\
\text { (inches of } \\
\text { water) }\end{array}$ \\
\hline 1.7 & 8.2 & 14.3 & $>2000^{2}$ & & 1 & 4.1 \\
\hline 2.1 & 10.4 & 14.0 & 33.3 & 41.9 & 0 & 4.3 \\
\hline 2.9 & 15.0 & 13.4 & 23.9 & 43.8 & 0 & 4.6 \\
\hline 3.4 & 18.1 & 13.1 & 23.5 & 44.0 & 0 & 4.9 \\
\hline 5 & 29.2 & 11.9 & 25.9 & 45.0 & 0 & 5.7 \\
\hline 6.7 & 43.8 & 10.6 & 27.7 & 44.1 & 0 & 7.1 \\
\hline
\end{tabular}

1. calculated from measured exhaust gas oxygen.

2. analyzer over range

Table 4-3. Results of Combustion Tests in Cast Iron Boiler at Firing Rate of 0.28 Gallons Per Hour

\begin{tabular}{|c|c|c|c|c|c|c|}
\hline $\begin{array}{c}\text { Exhaust } \mathrm{O} 2 \\
(\%)\end{array}$ & $\begin{array}{c}\text { Excess air } \\
(\%)\end{array}$ & $\begin{array}{c}\text { Exhaust } \mathrm{CO}_{2}{ }^{\prime} \\
(\%)\end{array}$ & $\begin{array}{c}\mathrm{CO} \\
(\mathrm{ppm} @ 3 \% \mathrm{O} 2)\end{array}$ & $\begin{array}{c}\text { NOx } \\
\text { (ppm @ 3\% } \\
\text { O2) }\end{array}$ & Smoke Number & $\begin{array}{c}\text { Air Pressure } \\
\text { (inches of } \\
\text { water) }\end{array}$ \\
\hline 1.15 & 5.4 & 14.7 & $>2000^{2}$ & 47.6 & 1 & 7.5 \\
\hline 1.4 & 6.7 & 14.5 & 35.8 & 50.1 & 0 & 8 \\
\hline 2.8 & 14.4 & 13.5 & 19.8 & 49.5 & 0 & 9 \\
\hline 3.7 & 20.0 & 12.8 & 21.8 & 51.5 & 0 & 10.1 \\
\hline 4.5 & 25.5 & 12.2 & 22.9 & 50.7 & 0 & 11 \\
\hline
\end{tabular}

1. calculated from measured exhaust gas oxygen.

2. analyzer over range 

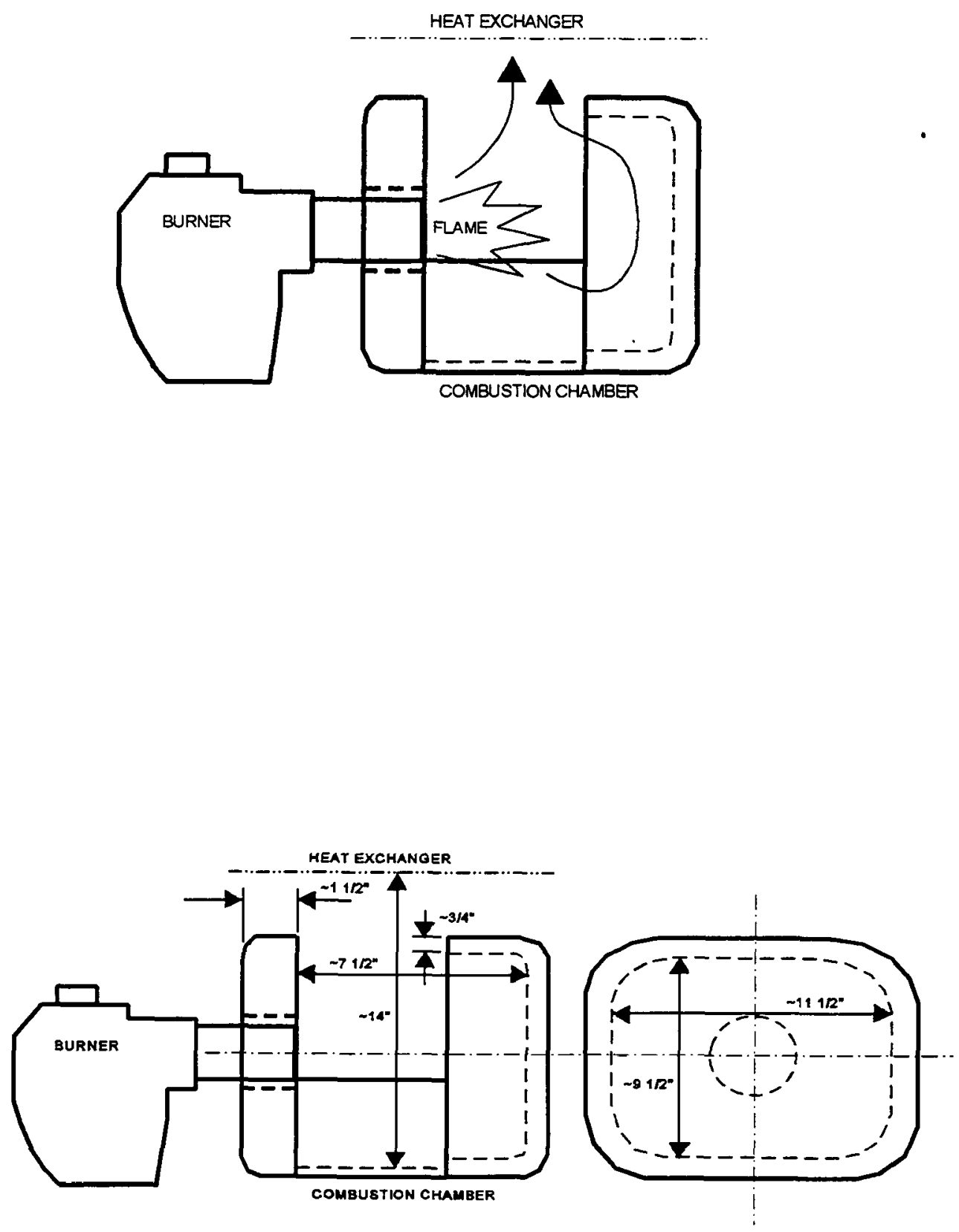

Combustion Chamber, Dimensions (Not to scale)

Figure 4-4. Illustration of the combustion chamber arrangement in two-section, cast iron boiler 
Generally in this application performance is very good and the burner can operate cleanly to low excess air level. In these test the flue gas temperature at the lower and higher firing rates were about 230 and $255 \mathrm{~F}$, respectively. These temperatures are lower than is considered good practice for chimney vented systems and the boiler is oversized for this application. Assuming a flue gas oxygen level of $3 \%$, or $15.6 \%$ excess air, the steady state efficiency at the low and high firing rates is $90.2 \%$, and $89.6 \%$ respectively. This is the "flue loss efficiency" and does not include appliance jacket losses.

Steel Boiler - This unit is a steel, horizontal firetube boiler illustrated in Figure 4-5. The combustion chamber is a horizontal cylinder, insulated for about $1 / 2$ the length by a lightweight refractory cylinder. The burner fires into the cylinder on axis at one end. At the opposite end of the combustion chamber products of combustion make a turn and flow back through the steel tubes which define the convective section.

Results of tests in this boiler are summarized in Table 4-4. In this boiler the $\mathrm{CO}$ levels, at moderate excess air levels $(>7 \%)$ are higher than is considered good practice with oil firing $(<50 \mathrm{ppm})$. Some additional tests were done in this application to reduce these levels. This included

Table 4-4. Results of Combustion Tests in Steel Boiler at Firing Rate of 0.28 Gallons Per Hour

\begin{tabular}{|r|r|r|r|r|r|r|}
\hline $\begin{array}{c}\text { Exhaust } \begin{array}{l}\text { O2 } \\
\text { (\%) }\end{array} \\
\text { (\%) }\end{array}$ & $\begin{array}{c}\text { Excess air }{ }^{1} \\
\text { (\%) }\end{array}$ & $\begin{array}{c}\text { Exhaust } \mathrm{CO}_{2}{ }^{2} \\
(\mathrm{ppm} @ 3 \% \mathrm{O} 2)\end{array}$ & $\begin{array}{c}\text { NOx } \\
(\mathrm{ppm} @ 3 \% \\
\mathrm{O} 2)\end{array}$ & $\begin{array}{c}\text { Smoke Number } \\
\text { (inches of } \\
\text { water) }\end{array}$ \\
\hline 1.2 & 5.7 & 14.7 & $>2000^{2}$ & 48.6 & 1 & 7.1 \\
\hline 1.8 & 8.8 & 14.2 & 98.4 & 51.1 & 0.5 & 7.5 \\
\hline 2 & 9.8 & 14.1 & 65.4 & 51.6 & 0 & 7.9 \\
\hline 3.4 & 18.1 & 13.1 & 74.7 & 50.6 & 0 & 9.5 \\
\hline 4.1 & 22.7 & 12.5 & 71.4 & 47.9 & 0 & 10 \\
\hline 4.7 & 27.0 & 12.1 & 69.6 & 47.5 & 0 & 11 \\
\hline 5.5 & 33.2 & 11.5 & 68.5 & 47.6 & 0 & 12 \\
\hline
\end{tabular}

1. calculated from measured exhaust gas oxygen.

2. analyzer over range

modifying the burner face to include a refractory quarl and adding a stainless steel liner to the inner surface of the refractory sleeve in the combustion chamber. Both of these measures were very effective in reducing the $\mathrm{CO}$ to under $50 \mathrm{ppm}$. It is expected that better performance can be achieved in this application in the future with simpler approaches.

At the $2 \%$ flue gas oxygen point listed in Table $4-4$, the flue gas temperature was $265 \mathrm{~F}$. The steady state efficiency at this point is $89.6 \%$, again based only on flue gas loss.

Up-Flow Warm Air Furnace - This unit is a fairly conventional warm air furnace and is illustrated in Figure 4-6. There is an up-flow heat exchanger mounted above an air handler compartment which contains a blower assembly. The heat exchanger consists of an inner and outer concentric cylinder. 

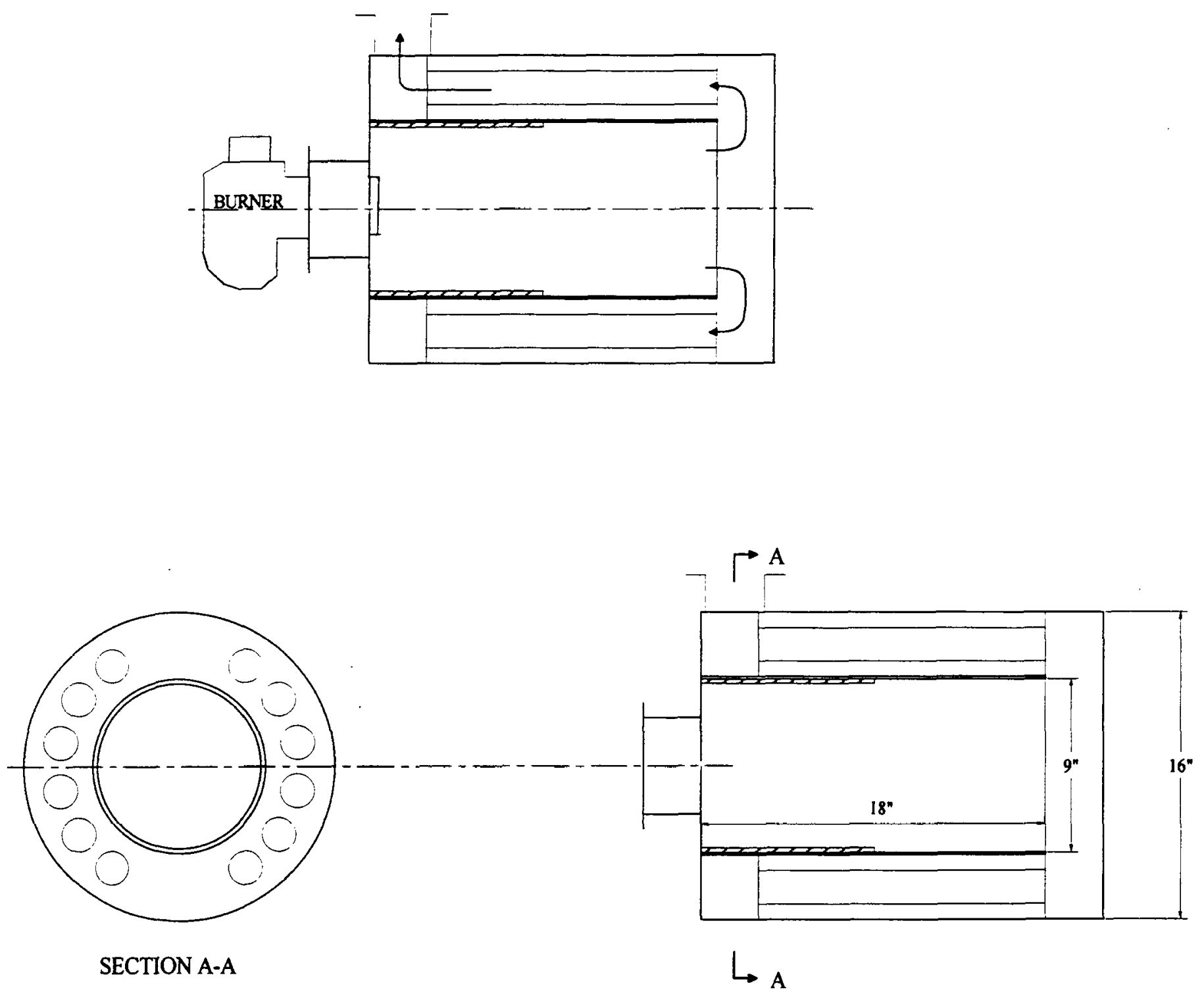

Figure 4-5. General arrangement of steel boiler tested. 

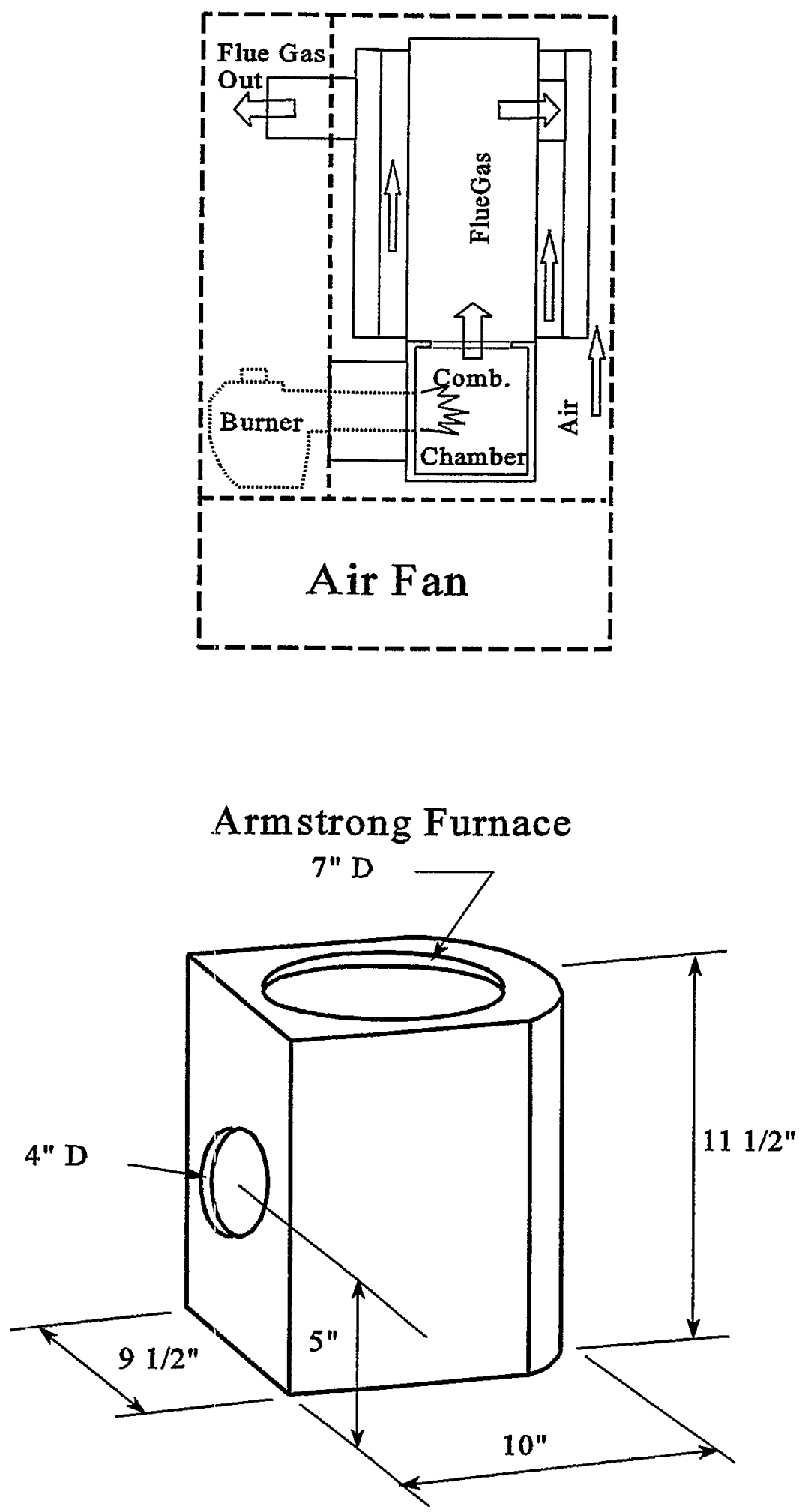

Figure 4-6 Illustration of up-flow warm air furnace 
The inner cylinder contains a combustion chamber at the bottom which contains a refractory chamber lining. Hot combustion gases move up from the combustion chamber to a point near the top of the inner cylinder where they flow rearward through a short connector to the outer cylinder. The gases flow through and around the interior of the outer cylinder until they reach a forward mounted connector to the flue exit. The exposed surfaces of the combustion chamber, the inner heat exchanger cylinder, and the outer heat exchanger cylinder are cooled by air flow from the air handler compartment below.

Test results with this furnace are summarized in Table 4-5. In this case the combustion performance is very good with low smoke and $\mathrm{CO}$ emissions to nearly stoichiometric conditions.

Table 4-5. Results of Combustion Tests in an Up-Flow Warm Air Furnace at Firing Rate of 0.28 Gallons Per Hour.

\begin{tabular}{|r|r|r|r|r|r|r|}
\hline $\begin{array}{r}\text { Exhaust O2 } \\
\text { (\%) }\end{array}$ & $\begin{array}{c}\text { Excess air } \\
\text { (\%) }\end{array}$ & $\begin{array}{c}\text { Exhaust } \mathrm{CO}_{2}{ }^{2} \\
(\%)\end{array}$ & $\begin{array}{c}\text { CO } \\
(\mathrm{ppm} @ 3 \% \text { 2) }\end{array}$ & $\begin{array}{c}\text { NOx } \\
(\mathrm{ppm} @ 3 \% \\
\mathrm{O} 2)\end{array}$ & $\begin{array}{c}\text { Smoke Number } \\
\text { (inches of } \\
\text { water) }\end{array}$ \\
\hline 0.6 & 2.8 & 15.1 & 19.4 & 57.4 & 0 & 7 \\
\hline 0.9 & 4.2 & 14.9 & 20.6 & 59.1 & 0 & 7.6 \\
\hline 1.2 & 5.7 & 14.7 & 20.0 & 59.1 & 0 & 7.6 \\
\hline 2.2 & 10.9 & 13.9 & 20.1 & 57.4 & 0 & 8.5 \\
\hline 2.7 & 13.8 & 13.6 & 20.7 & 62.0 & 0 & 8.2 \\
\hline 3.5 & 18.7 & 13.0 & 20.6 & 57.6 & 0 & 9.6 \\
\hline 4 & 22.0 & 12.6 & 19.1 & 54.0 & 0 & 10 \\
\hline 4.8 & 27.7 & 12.0 & 22.2 & 55.6 & 0 & 11.3 \\
\hline
\end{tabular}

1. calculated from measured exhaust gas oxygen.

At the $2.7 \%$ flue gas oxygen point listed in Table 4-5, the flue gas temperature was $203 \mathrm{~F}$. The steady state efficiency at this point is $90.9 \%$.

For this particular appliance additional tests were done to provide a direct comparison between the performance of this burner with the performance of the FAB (see Section 1) and a conventional pressure atomized retention head burner. While this comparison may be best done with each of these burners running at the same firing rate this was really not possible. Retnetion head burners with pressure atomization are not available with rated inputs under $0.5 \mathrm{gph}$. In addition, the HFAB as tested during the course of this program cannot run at rates much over about $0.25 \mathrm{gph}$ without using unrealistically high atomizing air pressures. For these reasons the comparison is made at rates as close as considered practical. Results are shown in Figure 4-7. The top chart in this fugure is smoke number. Here both the FAB and HFAB are shown to be able to operate at considerably lower excess air levels than the conventional burner without producing smoke. The middle chart shows $\mathrm{CO}$ and here all three burners produce similar, low $\mathrm{CO}$ levels. The bottom chart in Figure 4-7 is NOx and here the HFAB is considerably lower although some of this is likely due to the reduced firing rate. 
smoke number
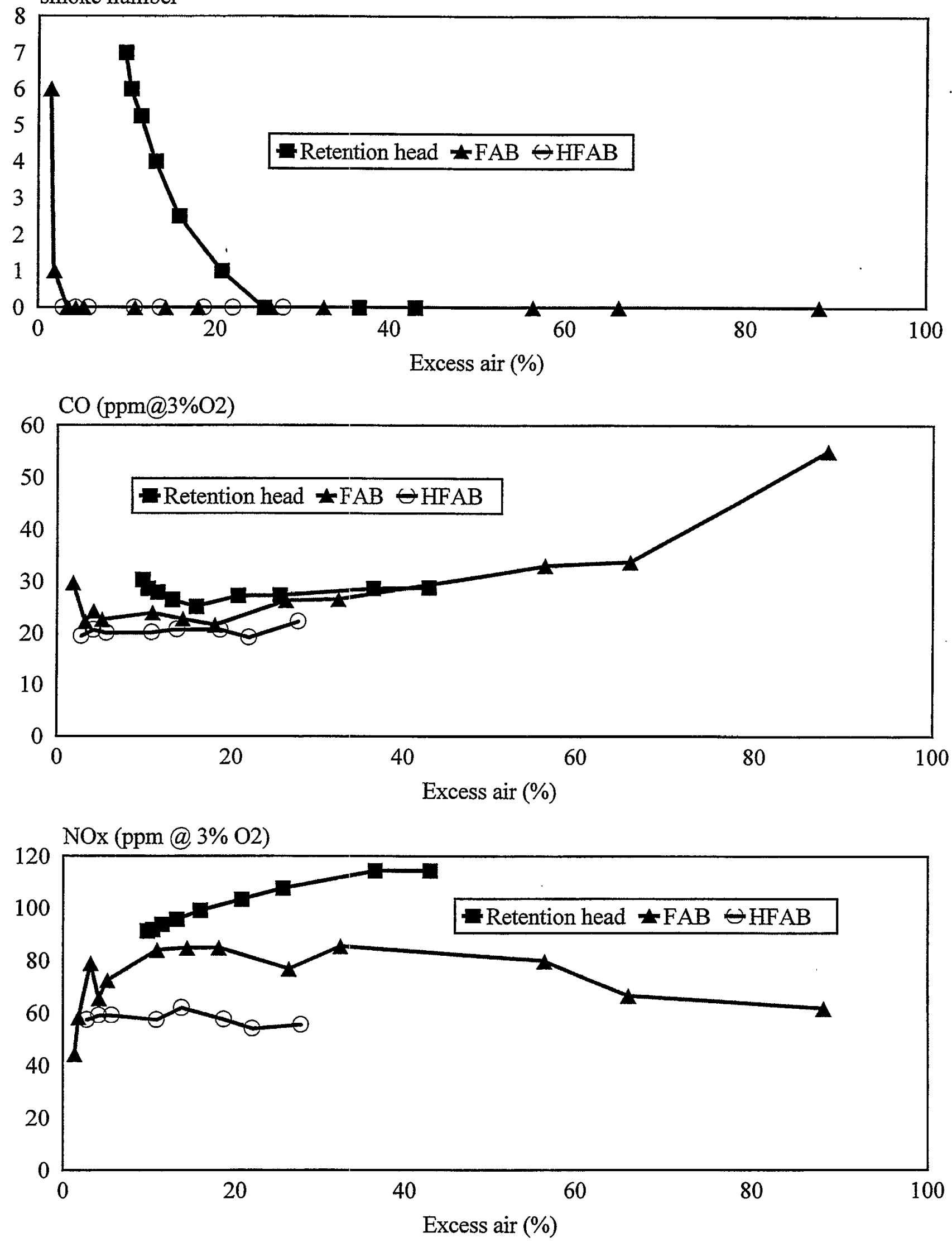

Figure 4-7. Up-flow warm air furnace. Comparison of performance: conventional retention head burner ( $0.5 \mathrm{gph})$; original Fan Atomized Burner ( $0.4 \mathrm{gph})$; and HFAB (0.28 gph). 
Warm Air Furnace with a Return Flow Combustion Chamber - This furnace is a fire-tube design in the general form of horizontal welded steel parallel passages set above a welded cylindrical combustion chamber as shown in Figure 4-8. The combustion chamber is devoid of any refractory lining or target wall. At the end of the chamber, the combustion gases are turned and forced to flow high along air cooled walls back to the front of the furnace where they enter a vertical collector. Here the gases are turned $180^{\circ}$ and flow through a single cylindrical breech connector passage to the breech located at the front of the furnace. All of the combustion gas handling components (combustion chamber, collectors, fire tubes, and breech connector) are cooled by the air flow used for space heating.

Combustion tests in this application were done at a firing rate of 0.27 gallons per hour and the results are summarized in Table 4-6. For these tests the burner was modified to include a larger (4") diameter flame tube. In addition, a refractory target wall was added to the chamber. Based on prior tests, the target wall does not significantly affect performance and the primary difference here is the larger flame tube.

Table 4-6. Results of Combustion Tests in a Warm Air Furnace with a Return Flow Combustion Chamber at a Firing Rate of 0.27 Gallons Per Hour.

\begin{tabular}{|c|c|c|c|c|c|c|}
\hline $\begin{array}{c}\text { Exhaust } \mathrm{O}_{2} \\
(\%)\end{array}$ & $\begin{array}{c}\text { Excess air } \\
(\%)\end{array}$ & $\begin{array}{c}\text { Exhaust } \mathrm{CO}_{2}{ }^{1} \\
(\%)\end{array}$ & $\begin{array}{c}\mathrm{CO} \\
\text { (ppm@3\%O2) }\end{array}$ & $\begin{array}{c}\text { NOx } \\
\text { (ppm@3\%O2) }\end{array}$ & $\begin{array}{c}\text { Smoke } \\
\text { Number }\end{array}$ & $\begin{array}{c}\text { Air Pressure } \\
\text { (inches of water) }\end{array}$ \\
\hline 0.3 & 1.4 & 15.4 & 88 & 49.6 & 2 & . \\
\hline 0.6 & 2.8 & 15.1 & 41 & 50.3 & .5 & 5.8 \\
\hline 1.2 & 5.7 & 14.7 & 35 & 51.8 & 0 & 6.0 \\
\hline 1.9 & 9.3 & 14.2 & 34 & 50.9 & 0 & 6.6 \\
\hline 2.7 & 13.8 & 13.6 & 32 & 51.1 & 0 & 7.0 \\
\hline 4.5 & 25.5 & 12.2 & 34 & 50.2 & 0 & 8.3 \\
\hline
\end{tabular}

1. calculated from measured exhaust gas oxygen.

Generally the flue gas temperature in these tests was under $200 \mathrm{~F}$. Certainly this firing rate is too low for this appliance and venting problems could be expected unless the unit is side-wall vented. 

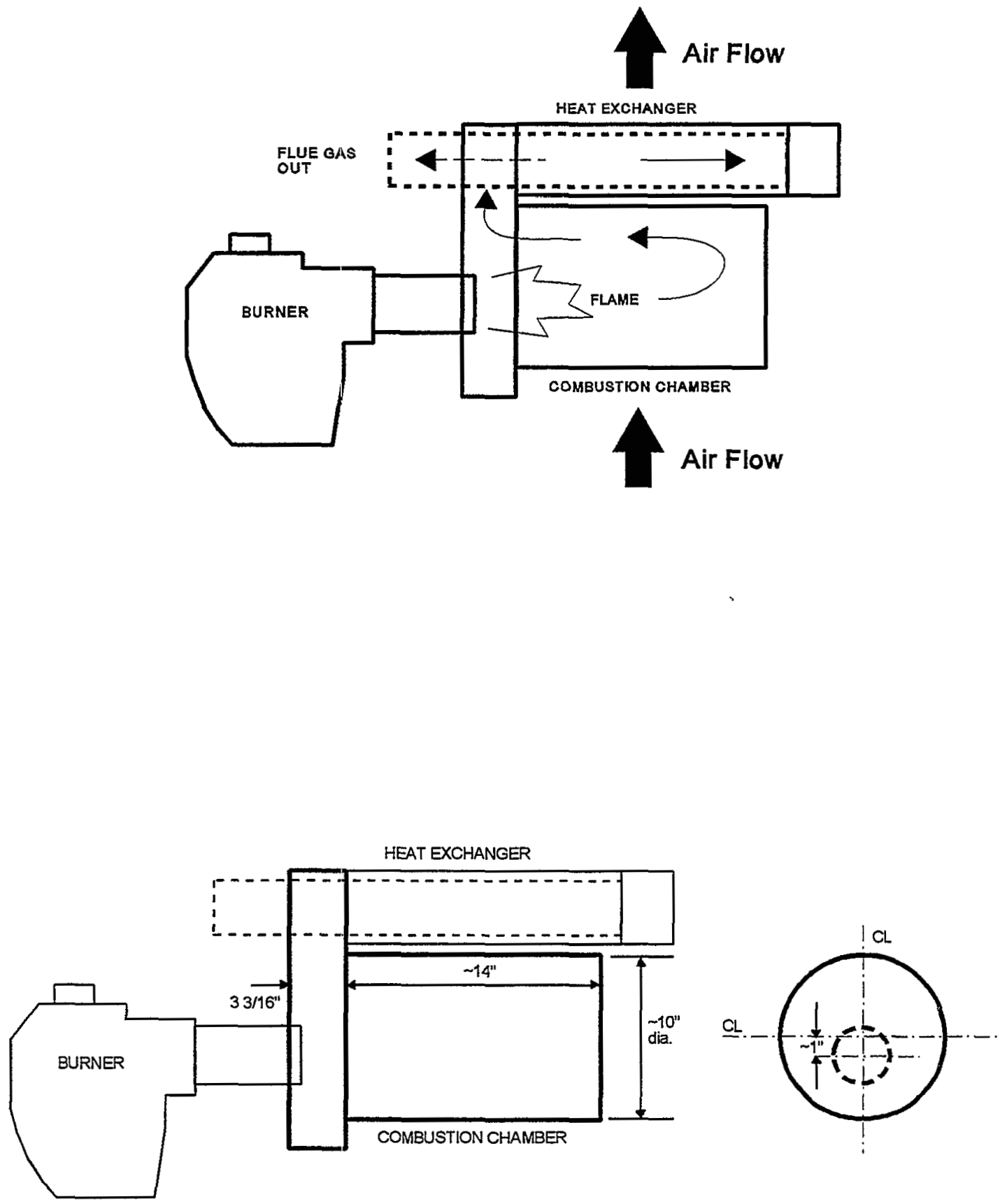

Combustion Chamber Dimensions (Not to scale)

Figure 4-8. Illustration of warm air furnace with a return flow combustion chamber 


\section{CONCLUSIONS AND FUTURE PLANS}

Based upon the development work and test results presented in this report the concept of a low pressure, air atomized residential oil burner with $100 \%$ of the air flow through the nozzle has significant potential. With this approach a stable flame can be obtained, the burner can be ignited from cold, and good combustion performance can be achieved. In all of the boilers and furnaces in which tests were done the burner was found to operate with essentially no smoke even at very low excess air levels. For some applications $\mathrm{CO}$ was higher than is considered acceptable and some additional application work would be required in these. In all cases NOx emission levels were very low.

Unique advantages which this burner provides include:

- simple head construction (relative to the FAB and common retention head burners)

- low firing rate capability (relative to retention head burners)

- good combustion performance

- low NOx emissions.

In future development work longer term testing is planned to evaluate coke buildup on head components in routine cyclic operation. For these tests an improved burner head prototype will be built which is closer to the expected commercial configuration. Machined head components will be replaced with stamped metal components wherever possible. As a method of achieving even lower NOx emissions the use of gas recirculation slots or holes in the flame tube will be explored. Plans also call for the development of a complete burner system including fuel pump and metering system, air supply, ignition transformer, and safety control. As tested in this program the burner head was operated at very low firing rates - under 0.3 gallons per hour. This range was specifically targeted to show that this concept can be used to extend the firing rate capability of available oil burners. It is recognized, however, that most of the market interest would be at somewhat higher firing rates. As part of future work potential ways to use this concept at higher rates will be explored. 


\section{REFERENCES}

1. Butcher, T., Fisher, L., Kamath, B., Kirchstetter, T., and Batey, J., Nitrogen oxides (NOx) and oil burners, Proceedings of the Eight Annual Oil Heat Technology Conference and Workshop, March 24-25, 1994, Upton N.Y.

2. Locklin, D.W., Hazard, H.R. Technology for the development of high-efficiency oil-fired residential heating equipment, Battelle Colombus Laboratories for BNL, BNL 51325, June 1980 .

3. Krajewski,R. Celebi,Y., Coughlan, R., Butcher, T., McDonald, R. Emissions characteristics of modern oil heating equipment. BNL 52249, July 1990.

4. Krishna, C.R., Butcher, T., and McDonald, R. Review of atomization and soot formation for advanced residnetial oil burner systems. BNL 52173, December 1987.

5. Fey, T. Pulsating oil flow for minimum capacity oil burners, Proceedings of the First European Conference on Snaall Burner Technology and Heating Equipment, Zurich, September 25-26, 1997. Eidgenössische Technische Hochschule, Zurich 1996.

6. Kirkelund, P. Low-capacity oil burners, The Danfoss Journal 4-1996.

7. Lefebvre, A.H. Gas Turbine Combustion, pp. 413-448. Hemisphere Publishing Corporation, 1983.

8. Butcher, Thomas A. Advanced oil burner for residential heating -- development report. BNL 62077, July 1995.

9. Butcher, T., Krajewski, R., Leigh, R. Celebi, Y., Fisher, L., and Kamath, B. Residential oil burners with low input and two-stage firing. ASHRAE Transactions 1997, V. 103, Pt. 1 .

10. Lefebvre, A.H. Gas Turbine Combustion, pp. 208-209. Hemisphere Publishing Corporation, 1983.

11. Beer, J.M. and Chigier, N.A.Combustion Aerodynamics, Chapter 5, Applied Science Publishers, London, 1974.

12. Butcher, T., McNeill, F., Celebi, Y., and Wegrzyn, J. Impact of burner design features on sooting in residential oil fired systems, BNL Report 52102, November 1986. 
